\title{
Role of oxidation of excitation-contraction coupling machinery in age-dependent loss of muscle
}

\section{function in C. elegans}

Haikel Dridi ${ }^{1}$, Frances Forrester ${ }^{1}$, Alisa Umanskaya ${ }^{1}$, Wenjun Xie ${ }^{1}$, Steven Reiken ${ }^{1}$, Alain Lacampagne ${ }^{2}$, Andrew R. Marks ${ }^{1,3}$

${ }^{1}$ Department of Physiology and Cellular Biophysics, The Clyde and Helen Wu Center for Molecular

Cardiology, ${ }^{2}$ Department of Medicine, Columbia University Vagelos College of Physicians and Surgeons New York, NY, USA.

${ }^{2}$ PhyMedExp, Montpellier University, INSERM, CNRS, CHRU Montpellier, 34295, Montpellier, France; Medical Intensive Care Unit, Montpellier University and Montpellier University Health Care Center, 34295, Montpellier, France.

${ }^{3}$ Address correspondence to: arm42@cumc.columbia.edu

Andrew Marks - Chair, Department of Physiology and Cellular Biophysics

Clyde and Helen Wu Professor of Medicine

Director, Wu Center for Molecular Cardiology

Russ Berrie Medical Science Pavilion

1150 St. Nicholas Avenue

New York, NY 10032

Phone: 212-851-5340 Fax: 212-851-5345

Email:arm42@columbia.edu 


\section{ABSTRACT}

Age-dependent loss of body wall muscle function and impaired locomotion occur within 2 weeks in $C$. elegans; however, the underlying mechanism has not been fully elucidated. In humans, age-dependent loss of muscle function occurs at about 80 years of age and has been linked to dysfunction of ryanodine receptor (RyR)/intracellular calcium $\left(\mathrm{Ca}^{2+}\right)$ release channels on the sarcoplasmic reticulum (SR). Mammalian skeletal muscle RyR1 channels undergo age-related remodeling due to oxidative overload, leading to loss of the stabilizing subunit calstabin1 (FKBP12) from the channel macromolecular complex. This destabilizes the closed state of the channel resulting in intracellular $\mathrm{Ca}^{2+}$ leak, reduced muscle function, and impaired exercise capacity. We now show that the $C$. elegans RyR homolog, UNC-68, exhibits a remarkable degree of evolutionary conservation with mammalian RyR channels and similar age-dependent dysfunction. Like RyR1 in mammals UNC-68 encodes a protein that comprises a macromolecular complex which includes the calstabin1 homolog FKB-2 and is immunoreactive with antibodies raised against the RyR1 complex. Further, as in aged mammals, $U N C-68$ is oxidized and depleted of FKB-2 in an age-dependent manner, resulting in "leaky" channels, depleted SR $\mathrm{Ca}^{2+}$ stores, reduced body wall muscle $\mathrm{Ca}^{2+}$ transients, and age-dependent muscle weakness. FKB-2 (ok3007)-deficient worms exhibit reduced exercise capacity. Pharmacologically induced oxidization of UNC-68 and depletion of FKB-2 from the channel independently caused reduced body wall muscle $\mathrm{Ca}^{2+}$ transients. Preventing FKB-2 depletion from the UNC-68 macromolecular complex using the Rycal drug S107 improved muscle $\mathrm{Ca}^{2+}$ transients and function. Taken together, these data suggest that UNC-68 oxidation plays a role in age-dependent loss of muscle function. Remarkably, this agedependent loss of muscle function induced by oxidative overload, which takes $\sim 2$ years in mice and $\sim 80$ years in humans, occurs in less than 2-3 weeks in C. elegans, suggesting that reduced anti-oxidant capacity may contribute to the differences in life span amongst species. 


\section{INTRODUCTION}

Approximately $50 \%$ of humans over the age of 80 develop muscle weakness, which contributes to falls and hip fractures, a leading cause of mortality in the elderly (1-3). Strikingly, despite an approximately 2,000-fold difference in the lifespans of humans and C. elegans $(4,5)$, both exhibit oxidative overload induced age-dependent reductions in muscle function and motor activity that ultimately contribute to senescence and death. Due to its short lifespan and well-characterized genome, C. elegans has been used as a model to study the genetics of aging and lifespan determination $(6,7)$, including the age-dependent decline in locomotion $(4,8)$. Age-dependent reduction in locomotion in C. elegans has been attributed to degeneration of the nervous system (9) and the body wall musculature (10). Here we investigated the role of the ryanodine receptor/ $\mathrm{Ca}^{2+}$ release channel (RyR) homolog, UNC-68, in age-dependent loss of muscle function in C. elegans.

Mammalian RyR1 is the major intracellular $\mathrm{Ca}^{2+}$ release channel in skeletal muscle required for excitation-contraction $(\mathrm{E}-\mathrm{C})$ coupling $(11,12)$. Peak intracellular $\mathrm{Ca}^{2+}$ transients evoked by sarcolemmal depolarization decrease with age (13), and this decrease is associated with a reduced SR $\mathrm{Ca}^{2+}$ release (14) that directly determines the force production of skeletal muscle. Our group has shown that a mechanism underlying age-dependent loss of muscle function is RyR1 channel oxidation which depletes the channel complex of the stabilizing subunit calstabin1 (calcium channel stabilizing binding protein type 1, or FKBP12), resulting in intracellular $\mathrm{Ca}^{2+}$ leak and muscle weakness $(15,16)$. RyR1 is a macromolecular complex comprised of homotetramers of four $~ 565 \mathrm{kDa}$ RyR monomers $(12,17)$. Cyclic AMP (cAMP) dependent protein kinase A (PKA) (18), protein phosphatase 1 (19), phosphodiesterase PDE4D3 (20), the $\mathrm{Ca}^{2+}$-dependent calmodulin kinase II (CaMKII) $(21,22)$, and calstabin1 (23), are components of the RyR1 macromolecular complex (24). Calstabin1 is part of the RyR1 complex in skeletal muscle and calstabin2 (FKBP12.6) is part of the RyR2 complex in cardiac muscle (25). Calstabins are immunophilins (26) with peptidyl-prolyl isomerase however this enzymatic activity does not play a role in regulating RyR channels and rather they stabilize the closed state of RyRs and prevent a $\mathrm{Ca}^{2+}$ leak via the channel $(18,27)$. 
RyR belongs to a small family of large intracellular calcium release channels, the only other member being the inositol 1,4,5-triphosphate receptor $\left(\mathrm{IP}_{3} \mathrm{R}\right)$ (28-30). RyR may have evolved from $\mathrm{IP}_{3} \mathrm{R}-\mathrm{B}$, which encoded an $\mathrm{IP}_{3} \mathrm{R}$-like channel that could not bind $\mathrm{IP}_{3}$ and was replaced by RyR at the Holozoa clade (31). Invertebrates have one gene for each of $\mathrm{RyR}$ and $\mathrm{IP}_{3} \mathrm{R}$, while vertebrates have three (RyR1-3 and IP $\left.{ }_{3} \mathrm{R} 1-3\right)$. RyRs and IP3Rs are intracellular $\mathrm{Ca}^{2+}$ release channels on the SR/ER and are tetramers that along with associated proteins comprise the largest known ion channel macromolecular complexes $(18,32)$. Defects in $\mathrm{Ca}^{2+}$ signaling linked to stressed-induced remodeling that results in leaky RyR channels have been implicated in heart failure $(33,34)$, cardiac arrhythmias $(33,35-38)$, diabetes (39), muscle weakness (40-43), and neurodegenerative disorders $(41,44,45)$.

RyR has evolved unique SPRY domains $(12,46)$ that are absent in $\mathrm{IP}_{3} \mathrm{R}$, one of which $(\mathrm{SPRY})$ allows RyR1 to directly interact with the L-Type Calcium channel (Cav1.1) in skeletal muscle (47). This interaction couples excitation of the sarcolemma to muscle contraction and eliminates dependence on extracellular $\mathrm{Ca}^{2+}$. RyR1 is remarkably well-conserved, suggesting that independence from extracellular $\mathrm{Ca}^{2+}$ evolved to support locomotion in higher organisms.

UNC-68 is the RyR gene homolog in the C. elegans genome (48). Worms lacking both exon 1.1 and promoter1 (49), and UNC-68 (e540) null mutants exhibit severely defective swimming behavior and locomotive characterized by the "unc", or "uncoordinated" phenotype (50). Treatment with ryanodine, a chemical ligand of RyR, induces contractile paralysis in wild-type C. elegans, whereas UNC-68 (e540) null mutants are unaffected by ryanodine $(48,50,51) . \mathrm{Ca}^{2+}$ transients triggered by action potentials in C. elegans body wall muscles require $U N C-68$.

We previously reported that in aged mice (2 years old equivalent to $\sim 80$ year old humans) oxidized, leaky RyR channels contribute to loss of muscle function and impaired muscle strength (16). In the present study, we show that UNC-68 is comprised of a macromolecular complex that is remarkably conserved compared to RyR1 and includes the channel-stabilizing subunit, $F K B$-2. Like calstabin, $F K B-2$ regulates $U N C-68$ by directly associating with the channel. Similar to what we previously observed in mice (15), we 
found age-dependent oxidation of $U N C-68$, depletion of $F K B-2$ from the $U N C-68$ channel complex, and reduced $\mathrm{Ca}^{2+}$ transients in aged nematodes. This aging phenotype was accelerated in FKB-2 (ok3007) worms, an $F K B-2$ deletion mutant that results in leaky $U N C$-68. Competing $F K B-2$ from $U N C$-68 with rapamycin or FK506 (52) resulted in reduced body wall muscle $\mathrm{Ca}^{2+}$ transients and oxidation of UNC-68. Conversely, pharmacological and genetic oxidation of UNC-68 with the reactive oxygen species (ROS)generating drug paraquat (53) reduced $F K B-2$ association with the channel and reduced contractionassociated $\mathrm{Ca}^{2+}$ transients. Re-associating FKB-2 with UNC-68 using the RyR-stabilizing drug S107 improved $\mathrm{Ca}^{2+}$ transients in aged nematodes. Our study provides an underlying mechanism for agedependent loss of muscle function in C. elegans, progressive oxidation of UNC-68, which renders the channel leaky within 2 weeks compared to 2 years in mice and 80 years in humans.

\section{RESULTS}

\section{Conserved evolution and architecture of UNC-68}

Phylogenic analysis of RyR and FKBP among species reveals remarkable evolutionary conservation (Figure 1A-B). UNC-68, the C. elegans intracellular calcium release channel, shares $\sim 40 \%$ homology with the human RyR1 (Figure 1C). C. elegans FKB-2 has $\sim 60 \%$ sequence identity with the skeletal muscle isoform calstabin1 (FKBP12) (Figure 1D). Based on these observations, we hypothesized that in C. elegans, UNC-68 comprises a macromolecular complex, similar to that of mammalian RyRs. To test this hypothesis, lysates were prepared from populations of freeze-cracked wild type C. elegans and UNC-68 was immunoprecipitated using mammalian anti-RyR antibody (5029) as previously described (54). The immunoprecipitates were immunoblotted to detect $U N C-68$, as well as other components of the RyR macromolecular complex including the catalytic subunit of protein kinase A $\left(\mathrm{PKA}_{\mathrm{cat}}\right)$, protein phosphatase 1 (PP1), FKB-2, and phosphodiesterase 4 (PDE-4) using mammalian anti-RyR, anti-PKA, anti-PP1, anticalstabin, and anti-PDE-4 antibodies, respectively (Figure 1E). The previously published C. elegans antiPDE-4 (55) was used to detect PDE-4 on the channel. Our data show that UNC-68 comprises a 
macromolecular complex, similar to that found in the mammalian muscle, that includes PKA $\mathrm{cat}_{\text {, }}$ PP1, PDE-4 and FKB-2. UNC-68 was depleted of FKB-2 in the FKB-2 (ok3007) null mutant (Figure 1E and G). In the FKB-2 null C. elegans, UNC-68 and the rest of the macromolecular complex could not be immunoprecipitated using an anti-FKBP antibody (Figure 1F and $\mathbf{H}$ ). Taken together these data indicate remarkable evolutionary conservation of the RyR macromolecular complex.

\section{Age-dependent biochemical and functional remodeling of UNC-68}

RyR1 channels are oxidized, leaky, and $\mathrm{Ca}^{2+}$ transients are reduced in aged mammalian skeletal muscle (15). These changes occur by two years of age in mice (15) and by 80 years of age in humans. Similarly, C. elegans exhibited an age-dependent decline in body wall muscle peak $\mathrm{Ca}^{2+}$ transients from day 3 to day 15 post-hatching (Figure 2 A-B).

RyR1 oxidation has been linked to $\mathrm{SR} \mathrm{Ca}^{2+}$ leak and impaired muscle function during extreme exercise and in heart failure and muscular dystrophies $(23,56,57)$. Furthermore, we have previously reported that oxidation of RyR1 and the subsequent intracellular $\mathrm{Ca}^{2+}$ leak are underlying mechanisms of age-related loss of skeletal muscle specific force (force normalized to the cross sectional area of muscle) (15). WT UNC-68 was depleted of FKB-2 (Figure 2C-D) and oxidized (Figure 2C-E) in an age-dependent manner. These changes mirror those occurring with extreme exercise in mice and humans (23) and in a murine model of Duchenne Muscular Dystrophy ( $\mathrm{mdx}$ mice) characterized by impaired muscle function (56). Importantly, by 80 years of age, $\sim 50 \%$ of humans develop severe muscle weakness that is a strong predictor of mortality due to falls, gait imbalance, and related factors (58).

\section{FKB-2 deficiency accelerates age-dependent reduction in $\mathrm{Ca}^{2+}$ transient that drives muscle contraction}

$F K B-2$ deficiency accelerated age-dependent reduction in body wall muscle $\mathrm{Ca}^{2+}$ transients (Figure 2A-B), with peak $\mathrm{Ca}^{2+}$ in $F K B-2(o k 3007)$ worms at day 7 being significantly lower than that of wild type at the same age. Similarly, $U N C$-68 was significantly more oxidized (day 3 to 9) in $F K B-2$ (ok3007) worms 
compared to wild type (Figure 2C, D, E).

\section{UNC-68 channels are leaky in the absence of FKB-2}

To further demonstrate that $U N C$-68 channels lacking $F K B-2$ are inherently 'leaky', we used an assay that can monitor the rate of $\mathrm{Ca}^{2+}$ released from the SR. Synchronized worm microsomes (day 5) were mixed with the $\mathrm{Ca}^{2+}$ dye Fluo-4 and baseline fluorescent measurements were taken before adding $1 \mathrm{mM}$ of ATP. By activating the sarco/endoplasmic calcium ATPase (SERCA) with ATP, cytosolic $\mathrm{Ca}^{2+}$ is pumped into the microsomes until the cellular compartment reaches capacity, resulting in a subsequent decrease in Fluo-4 fluorescence. Once the fluorescence level plateaus, thapsigargin (SERCA antagonist) is added to block $\mathrm{Ca}^{2+}$ re-uptake into the SR. The rate at which the fluorescence increases directly correlates with the amount of $\mathrm{Ca}^{2+}$ entering the cytoplasm: a higher increase of cytosolic $\mathrm{Ca}^{2+}$ compared to WT controls is suggestive of leaky UNC-68 channels. Our data show that $U N C-68$ from FKB-2 KO worms had a higher rate of $\mathrm{SR} \mathrm{Ca}^{2+}$ leak following thapsigargin administration compared to the WT channels (Figure 2F). This is corroborated by our previous findings, where disruption of RyR-calstabin binding increases the $\mathrm{SR}^{\mathrm{Ca}^{2+}}$ leak in mammalian tissues $(16,59)$.

\section{UNC-68 channel leak impairs exercise capacity}

In mammals, calstabin regulation of RyR is tightly coupled to beta-adrenergic signaling (60), and it is known that calstabin KO mice must undergo exercise stress before demonstrating a distinct muscle phenotype (23). Our method of inducing exercise stress in the worm was to place it in M9 buffer and observe it swimming, a well-described behavioral assay (61). By using an extended time trial of 2 hours, the worms fatigue and exhibit exercise-induced stress similar to that observed in mammals. Our data show a defect in $F K B-2 K O$ swimming behavior over the course of its lifespan when compared to the WT. $F K B-2 K O$ worms had decreased bending activity earlier in life, beginning at day 5, and an increased proportion of curling, a sign of fatigue (Figure 2G-H). Throughout midlife, the $F K B-2 \mathrm{KO}$ worms lag significantly behind their agematched WT counterparts, suggestive of decreased muscle function. Furthermore, $F K B-2 \mathrm{KO}$ worms exhibit 
reduced life span compared to WT (Figure 2I).

\section{Pharmacologically mimicking aging phenotype affects $\mathrm{Ca}^{2+}$ transient and impairs exercise capacity.}

$F K B$-2 was competed off from the $U N C$-68 macromolecular complex using rapamycin or FK506 (Figure 3).

Both rapamycin and FK-506 bind to calstabin and compete it off from RyR channels, resulting in leaky channels and release of $\mathrm{SR} \mathrm{Ca}^{2+}$ in the resting state $(27,62,63)$. Rapamycin-FKBP12 inhibits mTOR and FK506 inhibits calcineurin, indicating that these distinct non-UNC-68 related actions do not account for the observed SR $\mathrm{Ca}^{2+}$ leak.

Age-synchronized young C. elegans were treated with rapamycin or FK506. Acute treatment with FK506 or rapamycin each independently caused depletion of FKB-2 from the channel (Figure 3A, B, C). Furthermore, longer treatment of WT worms with FK506 caused oxidation of UNC-68, demonstrating a relationship between depletion of $F K B-2$ and oxidation of $U N C-68$ (Figure 3D, E, F).

$\mathrm{Ca}^{2+}$ transients were measured in partially immobilized transgenic nematodes expressing the genetically encoded $\mathrm{Ca}^{2+}$ indicator, Pmyo-3::GCaMP2, in the body wall muscle cells (64, 65) (Figure 3G). Pharmacologic depletion of $F K B-2$ from $U N C-68$ by rapamycin or FK506 treatment caused reduced body wall muscle $\mathrm{Ca}^{2+}$ transients in wild type C. elegans (Figure 3H). When FKB-2 was genetically depleted from the $U N C-68$ complex, as in the FKB-2 (ok3007) nematodes, treatment with rapamycin or FK506 had no effect on the $\mathrm{Ca}^{2+}$ transients (Figure 3H).

Continuous $\mathrm{Ca}^{2+}$ leak via $U N C-68$ would be expected to result in depleted $\mathrm{SR} \mathrm{Ca}^{2+}$ stores; therefore, we utilized a common technique from the mammalian RyR literature to evaluate the SR $\mathrm{Ca}^{2+}$ stores. In brief, an activating concentration of caffeine is used to fully open the RyR channel, leading to a rapid release of calcium from the SR into the cytoplasm. This increase can be approximated using a previously targeted, florescent calcium dye or indicator. Caffeine was applied to day 5 cut worms (Figure 3I) and the amount of fluorescence given off by GCaMP2 was measured. The GCaMP2-WT worms demonstrated a strong Ca ${ }^{2+}$ transient within 10 seconds of caffeine administration, while GCaMP2- $F K B-2 \mathrm{KO}$ worms failed to produce a response, suggesting that their $\mathrm{SR} \mathrm{Ca}^{2+}$ stores were too low to elicit one. Interestingly, GCaMP2-KO worms 
were observed as having very high background fluorescence, which may indicate an increase in cytosolic $\mathrm{Ca}^{2+}$ from passive $U N C-68$ leak. Indeed, rapamycin altered swimming behavior of WT but not $F K B-2 \mathrm{KO}$ worms in a time dependent manner (Figure 3J). Taken together with our $\mathrm{Ca}^{2+}$ transient data, the observed muscle phenotype appears to be the result of $U N C-68$ channel leak. These data suggest that rendering $U N C$ 68 channels leaky by removing $F K B-2$ depletes $\mathrm{SR} \mathrm{Ca}^{2+}$, resulting in reduced $\mathrm{Ca}^{2+}$ transients and weakened muscle contraction.

\section{Oxidation of UNC-68 causes reduced body wall muscle $\mathrm{Ca}^{2+}$ transients}

To investigate the individual effect of age-dependent $U N C$-68 oxidation independent of the other confounding variables involved in aging (4), we introduced a pharmacological intervention mimicking the aged state in young adult nematodes. Treating young adult nematodes with the superoxide-generating agent paraquat (53) increased oxidation of $U N C-68$ and depletion of $F K B-2$ from the channel in a concentrationdependent manner (Figure 4A, B, C). Furthermore, contraction-associated $\mathrm{Ca}^{2+}$ transients decreased with paraquat treatment in a concentration-dependent manner (Figure 4D). Indeed, treatment with antioxidant NAcetyl-L-cysteine (NAC) improved $\mathrm{Ca}^{2+}$ transient in $F K B-2 \mathrm{KO}$ worms (Figure 4E). These data indicate that both $U N C-68$ oxidation and $F K B-2$ depletion independently contribute to the observed aging body wall muscle deterioration.

To better clarify the role of oxidative stress in age-dependent $U N C$ - 68 remodeling and $\mathrm{Ca}^{2+}$ leak, we used two mutant mitochondrial electron transport chain (ETC): the complex I mutant, CLK-1, and the complex II mutant, MEV-1. CLK-1 worms contain a Complex I-associated mutation where they cannot synthesize their own ubiquinone (UQ), a redox active lipid that accepts and transfers electrons from Complex I or II to Complex III in the ETC. The reduction in Complex I activity of CLK-1 is associated in long living worms (66-68). In contrast, MEV-1 worms contain a complex II (succinate dehydrogenase) cytochrome B560 mutation (69-71), preventing electron transfer from succinate to fumarate and caused mitochondrial ROS production, which is associated with decreased lifespan, averaging only 9 days (70). 
Interestingly, we have seen increased $U N C-68$ oxidation and $F K B-2$ depletion in the short-lived mutant (MEV-1) compared to WT and long-lived mutant (CLK-1) worms (Figure 4F, G and H). Indeed, MEV-1 worms exhibited reduced exercise capacity compared to WT and CLK-1 worms (Figure 4I-J).

\section{UNC-68 $\mathrm{Ca}^{2+}$ channel is a potential therapeutic target in aging}

The small molecule Rycal S107 inhibits SR $\mathrm{Ca}^{2+}$ leak by reducing the stress-induced depletion of calstabin from the RyR channel complex $(56,72)$. Here, we show that treatment with S107 $(10 \mu \mathrm{M})$ for 3-5 hours re-associated $F K B-2$ with $U N C-68$ without significant effect on the channel oxidation (Figure 5A, B, C). Furthermore, treatment with $\mathrm{S} 107$ improved peak $\mathrm{Ca}^{2+}$ in an $F K B-2$ dependent manner, as demonstrated by the fact that treating the $F K B-2 \mathrm{KO}$ worms results in no change in peak $\mathrm{Ca}^{2+}$ (Figure 5D-E). Interestingly, S107 treatment reduced age-dependent impairment of exercise capacity in WT worms at day 15 (Figure 5F). Of note, S107 has no effect on the WT worms life span (Figure 5G). Furthermore, the treatment of the short-lived worms, MEV1, with S107 restored the FKB-2 association with UNC-68, despite the persistence of the channel oxidant (Figure 5H, I and J).

\section{DISCUSSION}

Taken together, our data show that the C. elegans intracellular $\mathrm{Ca}^{2+}$ release channel UNC-68 comprises a macromolecular complex which is highly conserved throughout evolution from nematodes to humans. In nematodes, the $U N C-68$ macromolecular complex is comprised of a similar array of regulatory subunits as the mammalian RyR1 channels: a phosphodiesterase PDE-4, a protein kinase PKA, a protein phosphatase PP1, and the immunophilin, $F K B-2$. Binding of $F K B-2$ (the $C$. elegans homolog of the mammalian RyR stabilizing protein calstabin) to the $U N C-68$ channel is required to prevent a pathological leak of intracellular $\mathrm{Ca}^{2+}$, similar to the manner observed in mammalian muscle (15). Aged C. elegans exhibit reduced $\mathrm{Ca}^{2+}$ transients, as well as oxidized $U N C-68$ channels and depleted $F K B-2$ by $\sim 2$ weeks of age. Each of these post-translational modifications of $U N C$-68 likely contribute to the aging phenotype, as 
pharmacologically depleting $U N C-68$ of $F K B-2$ and oxidizing the channel in young nematodes each independently result in a premature aging phenotype and reduce contraction-associated $\mathrm{Ca}^{2+}$ transients. Genetic FKB-2 deficiency causes an accelerated aging phenotype; $\mathrm{Ca}^{2+}$ transients are reduced in younger populations of $F K B-2(\mathrm{ok} 3007)$ nematodes and $U N C-68$ is oxidized at an earlier time point in these mutants relative to wild type. Treating aged wild type nematodes with the RyR-stabilizing drug, S107, re-associates $F K B-2$ with $U N C-68$ and increases the $\mathrm{Ca}^{2+}$ transients, indicating that $U N C-68$ dysfunction associated with oxidation-induced remodeling of the $U N C-68$ macromolecular complex is likely an underlying mechanism of age-dependent decrease in $\mathrm{Ca}^{2+}$ transients in function $C$. elegans body wall muscle.

C. elegans exhibit an aging muscle phenotype similar to age-dependent loss of muscle function in humans (15). This is characterized by impaired locomotion, reduction in muscle cell size associated with loss of cytoplasm and myofibrils, and progressive myofibril disorganization (4). However, specific body wall muscle proteins involved in the $C$. elegans aging phenotype have not been determined. Here, we show that $U N C-68$ is oxidized in aged nematodes and depleted of the channel-stabilizing protein, $F K B-2$. Our group has reported similar remodeling of RyR1 in skeletal muscle from aged mice (15) and in murine models of Muscular Dystrophies (56), all of which exhibit intracellular $\mathrm{Ca}^{2+}$ leak and reduced muscle specific force production.

Though the oxidative stress theory of aging was first proposed in $1956(73,74)$, there is still substantial controversy surrounding the role of ROS in aging. For example, deletion or overexpression of the ROS detoxification enzyme superoxide dismutase (SOD) has little effect on life span in C. elegans (75, 76). However, loss of sesn-1, the gene encoding sestrin, an evolutionarily conserved protein required for regenerating hyper-oxidized forms of peroxiredoxins and for ROS clearance, causes reduced lifespan (77). Furthermore, ROS levels measured in vivo in C. elegans increase with age (78). Other oxidative/antioxidative genes are involved in ROS production and may play a crucial role in the UNC-68 oxidation (Table S1). 
While the Free Radical Theory of Aging (FRTA) has taken a hit due to multiple observations that contradict the notion of a link between reduced oxidative load and longevity the preponderance of data shows a correlation between oxidative damage and reduced lifespan (79). Moreover, there is no doubt that reduced muscle function is detrimental to survival (80). The present study shows that a key effector of agedependent oxidative overload, RyR1 channel leak and the resulting muscle dysfunction, occur approximately 2,000 times faster in C. elegans compared to Homo sapiens and 50 times faster than in Mus musculus. Since the target system, RyR1/UNC68, are remarkably conserved and underlay dramatically similar physiological functions (namely $\mathrm{SR} \mathrm{Ca}^{2+}$ release required for muscle contraction) the cause for the accelerated kinetics of aging must be determined elsewhere and in an unrelentingly constant manner as exemplified by the rigid control of species lifespan. There is however, only one known case of a significant prolongation of lifespan in a species: Homo sapiens. Indeed, the average lifespan in the U.S. has doubled in the past century (81) largely due to improved sanitation and related public health measures that protect against communicable diseases, the present pandemic notwithstanding. This suggests that both environmental an $d$ intrinsic biological constraints can determine the limits of lifespan. Since we are a species that can remodel our environment to a greater extent than any other we have been able to double our lifespan by improving the environment although now global warming threatens to reverse this achievement. The unanswered question remains what are the intrinsic biological constraints on a given species longevity?

It would be interesting to know if the increased $U N C-68$ oxidation and subsequent reduction in body wall muscle $\mathrm{Ca}^{2+}$ transients are a result of globally increased ROS levels or increased ROS levels in $U N C$ 68-surrounding microdomains. For example, we have previously shown that inducing RyR leak in enzymatically dissociated skeletal muscle cells causes increased mitochondrial membrane potential and mitochondrial ROS production (15). Based on these data, we have proposed a model in which RyR1 leak (due to age-dependent oxidation of the channel) causes mitochondrial $\mathrm{Ca}^{2+}$ overload, resulting in $\mathrm{ROS}$ production, thus leading to further oxidation of RyR1 and exacerbation of the SR $\mathrm{Ca}^{2+}$ leak. This creates a 
vicious cycle between RyR1 and mitochondria that contributes to age-dependent loss of muscle function (82).

We also demonstrate that the putative null mutant, FKB-2 (ok3007), prevents $F K B-2$ from coimmunoprecipitating with $U N C-68$. The aging phenotype that we characterize in wild type nematodes (biochemically modified $U N C-68$ and reduced $\mathrm{Ca}^{2+}$ transients) is accelerated in $F K B-2$ (ok3007). There are eight $F K B$ s that are homologous to mammalian calstabin in the $C$. elegans genome; $F K B-1$ and $F K B-8$ both have $\sim 50 \%$ sequence identity to calstabin. Further studies could elucidate the possibility that in the absence of $F K B$-2, another $F K B$ may stabilize $U N C-68$, in particular the aforementioned $F K B$-8 (its gene is in close proximity to that of $F K B-2$ on chromosome 2) and $F K B-1$ (most similar to FKB-2 in terms of molecular weight). However, this appears not to be the case, since the aging phenotype is accelerated in the absence of $F K B-2$. Another key question is why $U N C-68$ becomes oxidized within two weeks, whereas the same posttranslational modification requires two years in mice and 80 years in humans (5). Given the high degree of conservation of RyR and other members of the complex (Figure 1), it is feasible that genetic screens in organisms such as C. elegans and Drosophila will yield additional crucial mediators that are common among species and explain disparities in lifespan such as genes-genes interactions, epigenetics or architecture and gating of key proteins involved in aging such as RyR. Indeed, despite the conservative evolution of $U N C$ - 68 , the channel contains higher number of methionine $(3.5 \%)$ and serine (7.2\%) (Table S2) compared to the human RyR1 (2.9\% and 5.9\% respectively). Methionine are a primary target of oxidative stress that might cause defects in the channel gating and alter $\mathrm{Ca}^{2+}$ release. Disparities in RyR1 serine residues among species, which are phosphorylation by protein kinases in response to stress, can cause conformational changes to the channel, exposing thereby more residues to oxidation and could be a potential mechanism responsible of the accelerated RyR1 oxidation in C. elegans.

Taken together, our data indicate that the C. elegans homolog of RyR, UNC-68, is comprised of a macromolecular complex and regulated by the immunophilin, $F K B-2$. We have identified age-dependent 
reduction in body wall muscle $\mathrm{Ca}^{2+}$ transients in nematodes that is coupled to oxidation and remodeling of UNC-68. SR $\mathrm{Ca}^{2+}$ stores are depleted in FKB2-KO worms, suggesting passive UNC-68 leak. This observation is supported by the $\mathrm{Ca}^{2+}$ leak assay results, which show that $F K B-2$ regulation is critical in preventing UNC-68 channels from aberrantly 'leaking' $\mathrm{Ca}^{2+}$ into the cytoplasm. With reduced $\mathrm{SR} \mathrm{Ca}^{2+}$, $U N C-68$ fails to release the burst of $\mathrm{Ca}^{2+}$ required for normal excitation-contraction coupling, leading to impaired muscle function. Loss of muscle function is evident in the $F K B-2 \mathrm{KO}$ worms during swimming trials, as middle-aged worms performed worse than their age-matched WT controls. Furthermore, our data strongly suggest a role for $F K B-2$ and $U N C-68$ in the age-dependent changes in $\mathrm{Ca}^{2+}$ signaling, as treatment with the pharmacological RyR stabilizer $\mathrm{S} 107$ increases body wall muscle $\mathrm{Ca}^{2+}$ transients.

\section{METHODS}

C. elegans strains and culture conditions 
Worms were grown and maintained on standard nematode growth medium (NGM) plates on a layer of OP50 Escherichia coli at $20^{\circ} \mathrm{C}$, as described (50). N2 (Bristol) and $f k b-2$ (ok3007) were provided by the Caenorhabditis Genetics Center (University of Minnesota). fkb-2 (ok3007) was backcrossed six times. The transgenic strain expressing Pmyo-3:GCaMP2 was kindly provided by Zhao-Wen Wang, University of Connecticut Health Center (65). Pmyo-3: GCaMP2 was subsequently crossed into fkb-2 (ok3007) for measurement of contraction-associated $\mathrm{Ca}^{2+}$ transients.

\section{Age synchronization}

Adult worms at the egg-laying stage were treated with alkaline hypochlorite solution to obtain agesynchronized populations and eggs were plated on NGM plates, as described (83). For experiments requiring aged worms, age-synchronized animals at the L4 stage were collected in M9 buffer and plated on NGM plates containing 5-fluoro-2'-deoxyuridine (FUDR, Sigma, $50 \mu \mathrm{M}$ ) to prevent egg-laying (84).

\section{Immunoprecipitation and immunoblotting}

Nematodes were grown under standard conditions. For protein biochemistry experiments, a procedure to crack nematodes in a solubilizing and denaturing buffer was adapted (85). Briefly, worms were washed and collected with M9 buffer, centrifuged for 2 minutes at 1,000 rpm three times to wash. Worms were allowed to settle to the bottom of the collection tube by sitting on ice for $\sim 5$ minutes. Fluid was removed and the worm pellet was snap frozen in liquid nitrogen. Frozen pellets containing whole nematodes were rapidly thawed under warm running water. A volume of Nematode solubilization buffer equal to the volume of the worm pellet was added (Nematode solubilization buffer: 0.3\% Ethanolamine, 2 mM EDTA, $1 \mathrm{mM}$ PMSF in DMSO, $5 \mathrm{mM}$ DTT, 1x protease inhibitor) and tubes were microwaved (25 s for $100 \mu \mathrm{l}$ pellet; time was increased for greater volumes). Lysates were then quickly drawn into a syringe through a 26-gauge needle and forced back through the needle into a new collection tube on ice. Samples were centrifuged at 1,000 rpm 
for 2 min to remove insoluble material and the supernatant was transferred to a new tube on ice. Lysates were snap frozen and stored in at $-80^{\circ} \mathrm{C}$.

A anti-mammalian RyR antibody (4 $\mu \mathrm{g} 5029 \mathrm{Ab}(86))$ was used to immunoprecipitate UNC-68 from $100 \mu \mathrm{g}$ of nematode homogenate. Samples were incubated with the antibody in $0.5 \mathrm{ml}$ of a modified RIPA buffer (50 mM Tris- $\mathrm{HCl} \mathrm{pH}$ 7.4, 0.9\% NaCl, 5.0 mM NaF, $1.0 \mathrm{mM} \mathrm{Na3VO4,} 1 \%$ Triton- X100, and protease inhibitors) for $1 \mathrm{hr}$ at $4^{\circ} \mathrm{C}$. The immune complexes were incubated with protein A Sepharose beads (Sigma, St. Louis, MS) at $4^{\circ} \mathrm{C}$ for 1 hour, after which time the beads were washed three times with buffer. Proteins were size-fractionated by SDS-PAGE (6\% for UNC-68, 15\% for FKB-2) and transferred onto nitrocellulose membranes for 1 hour at $200 \mathrm{~mA}$ (SemiDry transfer blot, Bio-Rad). After incubation with blocking solution (LICOR Biosciences, Lincoln NE) to prevent non-specific antibody binding, immunoblots were developed using antibodies against RyR (5029, 1:5000), PKAcat (Santa Cruz Biotechnology, sc-903, 1:1000), PDE4 (kindly provided to us by Kenneth Miller, Oklahoma Medical Research Foundation, Oklahoma City, Oklahoma), PP1 (sc6104, 1:1000) or an anti-calstabin antibody (Santa Cruz 1: 2,500). To determine channel oxidation, the carbonyl groups on the protein side chains were derivatized to 2,4-dinitrophenylhydrazone (DNP-hydrazone) by reaction with 2,4-dinitrophenylhydrazine (DNPH) according to manufacturers (Millipore) instructions. The DNP signal on immunoprecipitated UNC-68 was determined by immunoblotting with an anti-DNP antibody (Millipore, 1:1000). All immunoblots were developed and quantified using the Odyssey Infrared Imaging System (LICOR Biosystems, Lincoln, NE) and infraredlabeled secondary antibodies. In addition, immunoblotting and immunoprecipitation of the UNC-68 macromolecular complex were conducted using another anti-calstabin antibody (1:2000, Abcam) and the same methods as described.

\section{Imaging contraction-associated body wall muscle $\mathrm{Ca}^{2+}$ transients}

Spontaneous changes in body wall muscle $\mathrm{Ca}^{2+}$ were measured in nematodes expressing GCaMP2 by fluorescence imaging using a Zeiss Axio Observer inverted microscope with an electron-multiplying CCD 
camera (Photometrics Evolve 512) and an LED light source (Colibri). Nematodes were partially immobilized by placing them individually into a 5-10 $\mu$ drop of M9 buffer, suspended between a glass slide and coverslip. Twenty-second videos of individual nematodes were recorded.

Analyzing contraction-associated body wall muscle $\mathrm{Ca}^{2+}$ transients

Contraction-associated body wall muscle $\mathrm{Ca}^{2+}$ transients were analyzed using an Interactive Data Language (IDL)-based image quantification software that was developed for this purpose in our laboratory. For each twenty-second video, signals from the body wall muscles in nematodes expressing GCaMP2 fluorescence were analyzed using an edge-detection algorithm from each frame as "line-scan" images, with the nematode perimeter on the $y$-axis and time (s) on the $x$-axis $(87,88)$. These images were then quantified based on the average of the peak $\mathrm{Ca}^{2+}$ fluorescence signal on the worm muscle wall.

\section{Drug treatment}

To pharmacologically deplete FKB-2 from $U N C$-68, nematodes were treated for 15 minutes with $15 \mu \mathrm{M}$ rapamycin or imaging $50 \mu \mathrm{M}$ FK506, respectively. To re-associate FKB-2 and UNC-68, aged nematodes were treated with $10 \mu \mathrm{M} \mathrm{S107}$ for 3-5 hrs. Oxidative stress was induced in the worms using $20 \mathrm{mM}$ paraquat, a known generator of superoxide (89). Nematodes were grown in standard conditions, age-synchronized as described, washed and collected with M9 buffer, then centrifuged for 2 min at 1,000 rpm three times. Worms were allowed to settle to the bottom of the collection tube by sitting on ice for $\sim 5$ min. Fluid was removed, the worm pellet was gently resuspended in M9 containing the appropriate drug concentration and gently rocked on a shaker at RT for the indicated time periods. Collection tubes were centrifuged for 2 min at 1,000 rpm and M9 containing drug was removed and replaced with M9. Biochemistry or $\mathrm{Ca}^{2+}$ measurements were then conducted as previously described (16).

Measuring SR $\mathrm{Ca}^{2+}$ stores using caffeine activation 
Age-synchronized GCaMP2: WT and GCaMP2: FKB-2 KO were grown on NGM plates at $20^{\circ} \mathrm{C}$ they were separated from their progeny and left undisturbed until Day 5. Individual worms were placed in a drop of M9 on a coverslip. The liquid was carefully wicked away using KIMTECH wipes until only a sliver of moisture surrounded the worm. The worm was quickly glued down to the coverslip using a tiny drop of DermaWorm applied to the head and tail of the worm before the worm desiccated. $80 \mu$ of M9 buffer was added immediately afterwards to polymerize the glue. Once the worm was secure, a clean lateral cut to the immediate tail region was made using a 20G 11/2 needle (adapted from Wang ZW et al. Neuron 2011 ${ }^{48}$ ). An additional $170 \mu \mathrm{l}$ of M9 buffer was applied for a total of $250 \mu \mathrm{l}$. The completed preparation was placed on the platform of a Zeiss confocal microscope; after $1 \mathrm{~min}$ at baseline, $25 \mathrm{mM}$ of caffeine was added to an equal volume of M9 solution. The resulting body-wall transients were recorded for $1 \mathrm{~min}$.

\section{Calcium leak assay}

Worm microsomes from Day 5 synchronized populations $(0.25 \mathrm{mg})$ were added to $150 \mu \mathrm{l}$ solutions that contained: $20 \mathrm{mM}$ HEPES ph 7.2, $7 \mathrm{mM} \mathrm{NaCl}, 1.5 \mathrm{mM} \mathrm{MgCl} 2,0.1 \mathrm{mM}$ EGTA Ca ${ }^{2+}$ buffer (free $\left[\mathrm{Ca}^{2+}\right] 0.3$ $\mu \mathrm{M}), 8 \mathrm{mM}$ phosphocreatine, and $0.02 \mathrm{mM}$ fluo-4, $\mathrm{pH} 6.8 . \mathrm{Ca}^{2+}$ uptake was initiated by adding of $1 \mathrm{mM}$ ATP, which was allowed to plateau after 3 min. After the $\mathrm{Ca}^{2+}$ uptake had stabilized, $3 \mu \mathrm{M}$ thapsigargin was added to inhibit SERCA activity and the resulting $\mathrm{Ca}^{2+}$ leak was quantified fluoroscopically using a Tecan infinite F500 plate reader for $9 \mathrm{~min}$.

\section{Swimming behavior}

Standard M9 buffer was mixed with $2 \%$ agar and poured into 96 well plates to create a planar surface for analyzing worm swimming behavior. Once the mixture had polymerized, approximately $180 \mu \mathrm{l}$ of M9 was pipetted on top of the agar bed and age-synchronized worms from one of two groups (WT or FKB-2 KO) were placed individually into each well. To assess differences in exercise fatigue, worms were allowed to swim freely in M9 buffer for 2 hrs; swimming bends and curls (61) were recorded by eye for 1 min. 
Representative videos were taken of each group and investigators were blinded over the course of each experiment. All recordings were made in duplicate.

\section{Statistical analysis}

All results are presented as mean \pm SEM. Statistical analyses were performed using an unpaired two-tailed Student's t test (for 2 groups) and one-way ANOVA with Tukey-Kramer test (for 3 or more groups), unless otherwise indicated. $\mathrm{P}$ values $<0.05$ were considered significant. All statistical analyses were performed with Prism 8.0.

\section{Acknowledgments}

This work was supported by grants from the NIH to ARM (T32HL120826, R01HL145473, R01DK118240, R01HL142903, R01HL061503, R01HL140934, R01AR070194).

Author contributions: HD, FF and ARM designed experiments, analyzed data and edited/wrote the paper. AL, XL, QY, SR, RO, and PS designed experiments and analyzed data.

Competing interests: Columbia University and ARM own stock in ARMGO, Inc. a company developing compounds targeting RyR and have patents on Rycals. 
$A$

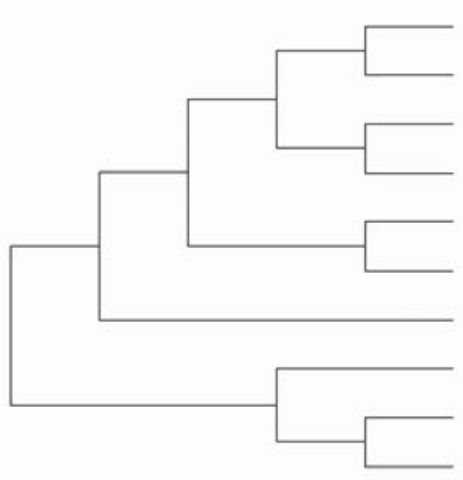

RyR1 Ryanodine receptor 1 Human

RyR1 Ryanodine receptor 1 Rabbit

RyR1 Ryanodine receptor 1 Pig

RyR1 Ryanodine receptor 1 Dog

RyR1 Ryanodine receptor 1 Mouse

RyR1 Ryanodine receptor 1 Rat

Ryanodine receptor 1a (skeletal) Zebrafish

Ryanodine receptor Caenorhabditis elegans (UNC-68)

Ryanodine receptor Chilo suppressalis

Ryanodine receptor isoform A Drosophila melanogaster
$D$

\begin{tabular}{|l|c|c|c|}
\hline Protein & Human FKBP12 & Human FKBP12.6 & Estimated MW \\
\hline FKB-1 & $48 \%$ ID; $68 \%$ Pos & $46 \%$ ID; $65 \%$ Pos & $15.5 \mathrm{kDa}$ \\
\hline FKB-2 & $61 \%$ ID; $72 \%$ Pos & $57 \%$ ID; $73 \%$ Pos & $11.6 \mathrm{kDa}$ \\
\hline FKB-3 & $43 \%$ ID; $58 \%$ Pos & $41 \%$ ID; $57 \%$ Pos & $29.1 \mathrm{kDa}$ \\
\hline FKB-4 & $36 \%$ ID; $49 \%$ Pos & $31 \%$ ID; $46 \%$ Pos & $29.3 \mathrm{kDa}$ \\
\hline FKB-5 & $42 \%$ ID; $51 \%$ Pos & $38 \%$ ID; $48 \%$ Pos & $29.9 \mathrm{kDa}$ \\
\hline FKB-6 & $53 \%$ ID; $64 \%$ Pos & $51 \%$ ID; $60 \%$ Pos & $48 \mathrm{kDa}$ \\
\hline FKB-7 & $20 \%$ ID; $41 \%$ Pos & No significant ID & $36.1 \mathrm{kDa}$ \\
\hline FKB-8 & $51 \%$ ID; $66 \%$ Pos & $47 \%$ ID; $63 \%$ Pos & $32.3 \mathrm{kDa}$ \\
\hline
\end{tabular}

FKBP12 Human

FKB-2 Caenorhabditis elegans

FKB-3 Caenorhabditis elegans

FKB-4 Caenorhabditis elegans

FKB-7 Caenorhabditis elegans

FKB-5 Caenorhabditis elegans

FKB-8 Caenorhabditis elegans

FKB-1 Caenorhabditis elegans

FKB-6 Caenorhabditis elegans

\section{C}

\begin{tabular}{|c|c|c|c|}
\hline Protein & Human RyR1 & Human RyR2 & Estimated MW \\
\hline UNC-68 & $37 \%$ ID; 55\% Pos & $39 \%$ ID; $57 \%$ Pos & $605 \mathrm{kDa}$ \\
\hline
\end{tabular}

FKBP12.6 Human

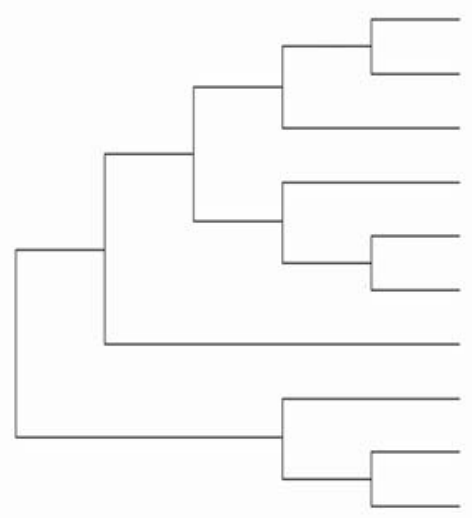

$E \quad F \quad G$

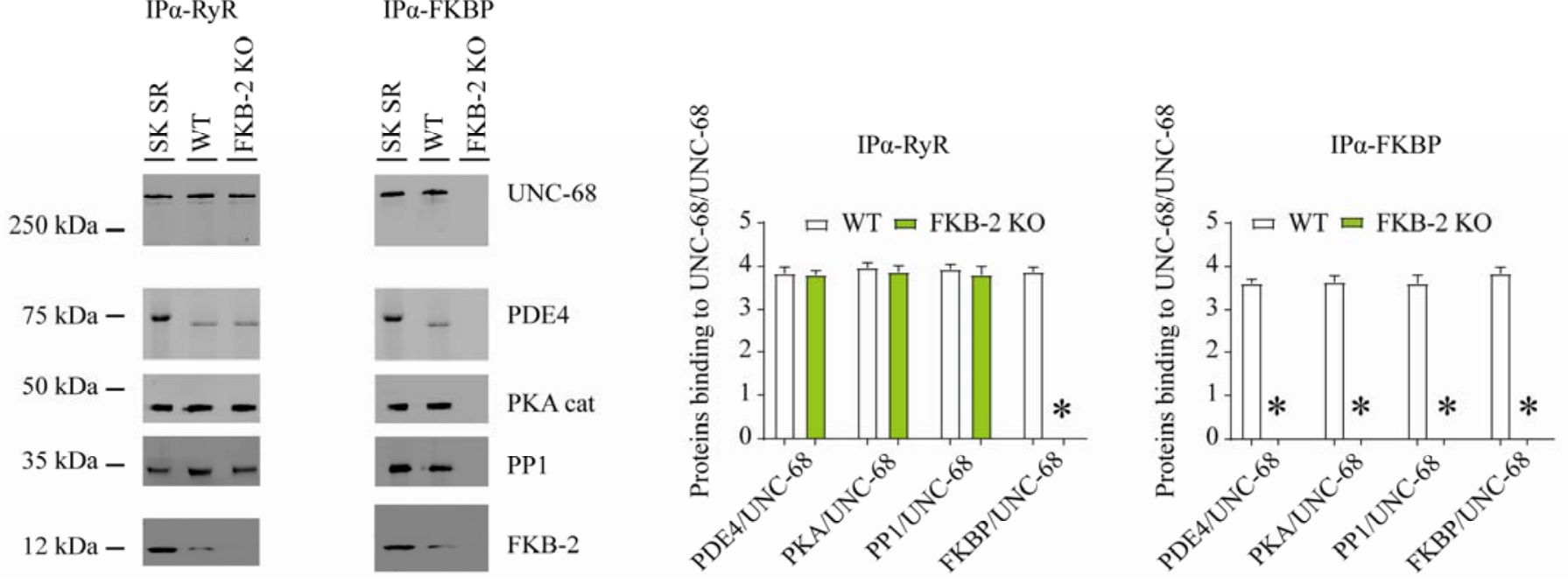

Figure 1: UNC-68 comprises a macromolecular complex comparable to its mammalian homologue RyR; RyR (A) and FKBP (B) evolution among species was inferred by the maximum likelihood method based on the JTT matrix-based model. (C) Homology comparison between UNC-68 and the two human RyR isoforms (RyR1 and RyR2). (D) Homology comparison between the different FKB isoforms (1 to 8) and the 
human FKBP isoforms (FKBP12 and FKB12.6). UNC-68 (E) and FKB-2 (F), respectively, were immunoprecipitated and immunoblotted using anti-RyR, anti-phosphodiesterase 4 (PDE4), anti-protein kinase A (catalytic subunit; PKAcat), anti-protein phosphatase 1 (PP1), and anti-Calstabin (FKBP) antibodies in murine skeletal sarcoplasmic reticulum preparations (Sk SR), wild type populations of $C$. elegans (WT), and populations of $F K B-2$ (ok3007). Images show representative immunoblots from triplicate experiments. ( $\mathrm{G}$ and $\mathrm{H}$ ) quantification of bands intensity shown in $\mathrm{E}$ and $\mathrm{F}$. $\mathrm{N}=6$ per group. Data are means \pm SEM. One-way ANOVA shows * $\mathrm{P}<0.05$ WT vs. FKB-2 KO. SK SR; Sarcoplasmic reticulum fraction from mouse skeletal muscle. 
$A$
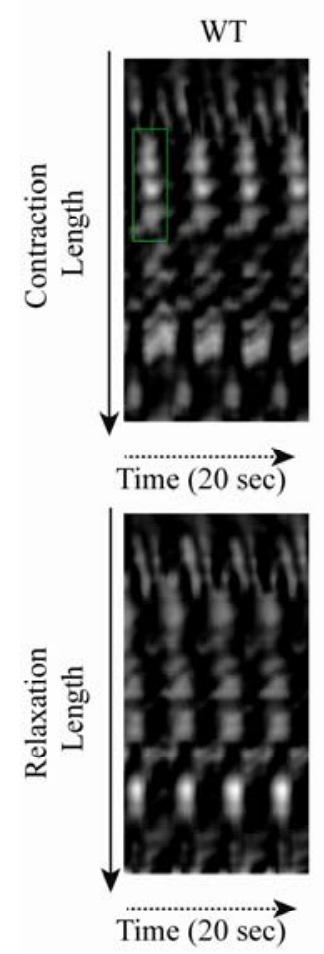

FKB-2 KO
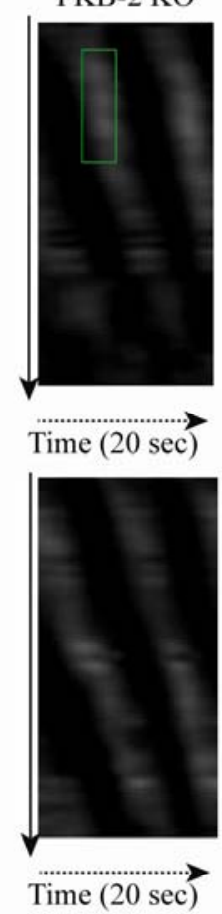

WT

$F$

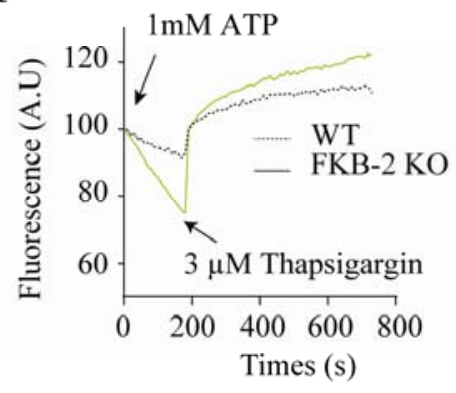

$I$

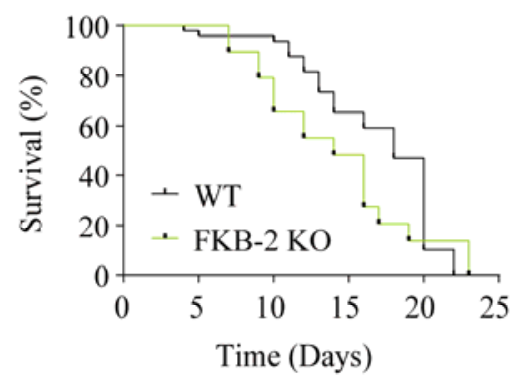

$B$
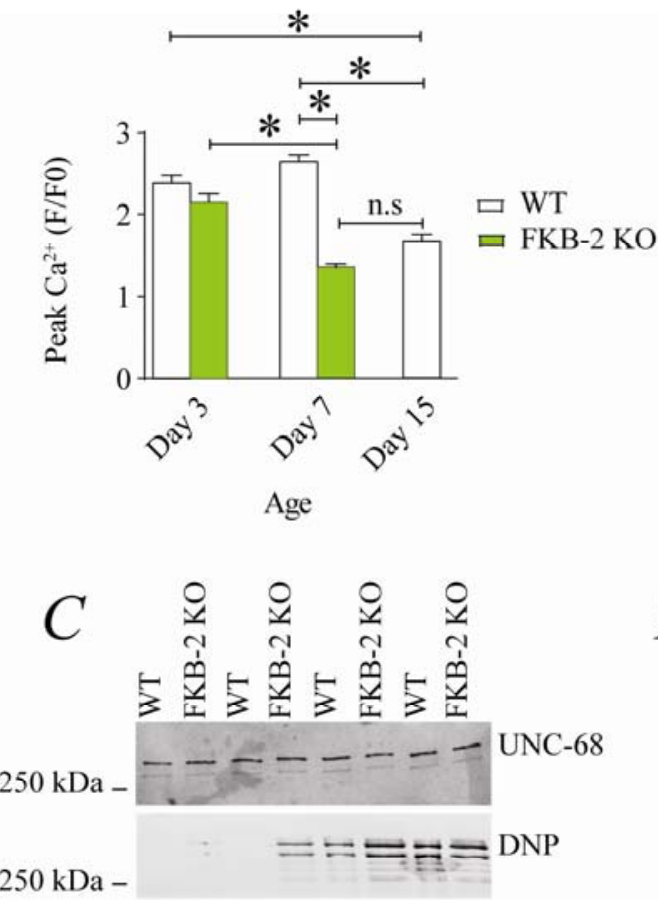

$12 \mathrm{kDa}-$

FKB-2

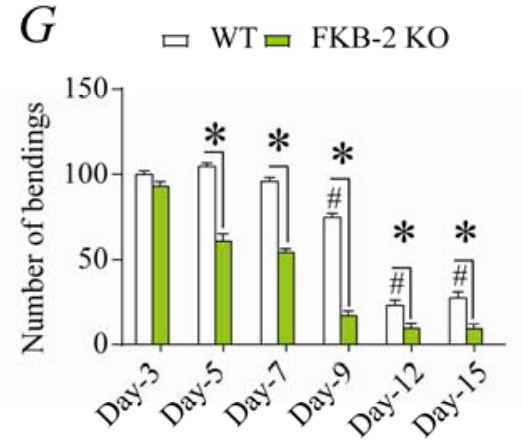

$H$
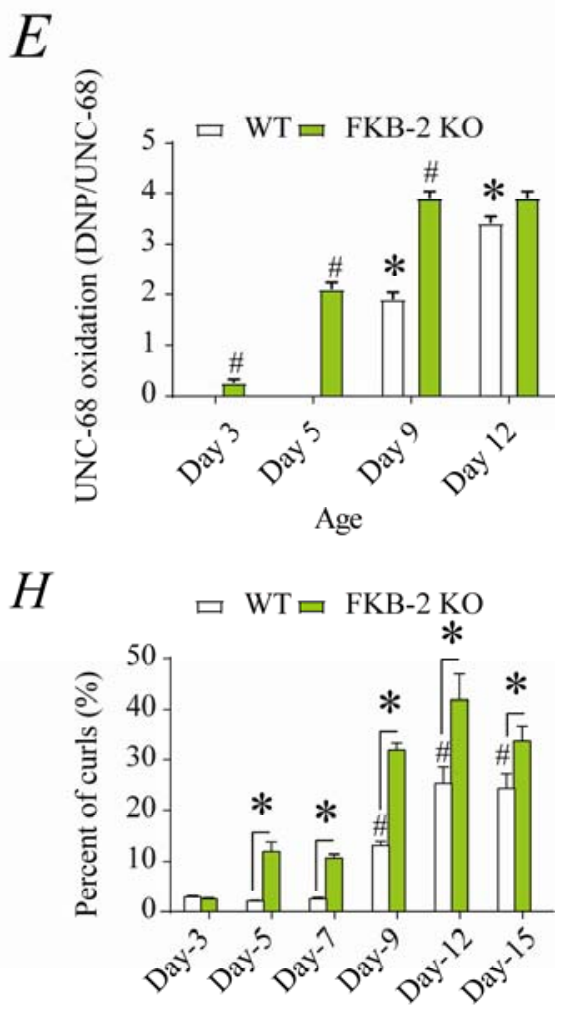

Figure 2: Remodeling of UNC-68 and age-dependent reduction in $\mathrm{Ca}^{2+}$ transients is accelerated in FKB-2 (ok3007) (A) Representative trace of $\mathrm{Ca}^{2+}$ transients from GCaMP2 WT and FKB-2 KO. Green box denotes peak fluorescence from worm's muscle during contraction. (B) $\mathrm{Ca}^{2+}$ transients in age-synchronized populations of wild type and FKB-2 (ok3007) nematodes; (C) UNC-68 was immunoprecipitated from age- 
synchronized populations of mutant (FKB-2 KO) and WT nematodes and immunoblotted using anti-RyR, anti-Calstabin and DNP (marker of oxidation) antibodies. (D) and (E) Quantification of the average band intensity from triplicate experiments: band intensity was defined as the ratio of each complex member's expression over its corresponding /UNC-68's expression Data are means \pm SEM. * $\mathrm{P}<0.05$ WT vs. FKB-2 KO in panel D, \# $\mathrm{P}<0.05$ WT vs. FKB-2 KO in panel E, * $\mathrm{P}<0.05 \mathrm{WT}$ at Day3 vs. WT at Day5 and Day9. (F) $\mathrm{Ca}^{2+}$ leak assay performed with microsomes from WT and FKB-2 KO worms (Day 5). $\mathrm{Ca}^{2+}$ uptake into the microsomes was initiated by adding $1 \mathrm{mM}$ of ATP. Then, $3 \mu \mathrm{M}$ of thapsigargin was added to block the SERCA activity. Increased fluorescence is proportional to the spontaneous $\mathrm{Ca}^{2+}$ leakage throughout UNC-68. (G) Graph showing number of bends recorded for WT vs FKB-2 KO worms at six distinct ages (Day 3, 5, 7, $9,12,15)$. (H) Number of curling events were calculated as a percentage of the overall motility (curls/bends). $\mathrm{N}=\sim 60$ worms per group, with the exception of Day 15 (as fewer worms were alive at this time point). Day $15=\sim 40$ worms. (I) percentage of survival of WT and FKB-2 KO worms. Data are means \pm SEM. One Way ANOVA shows * $\mathrm{P}<0.05$ WT vs. FKB-2 KO, \# P<0.05 WT at Day3 vs. Day5-7-9-12 and 15. 

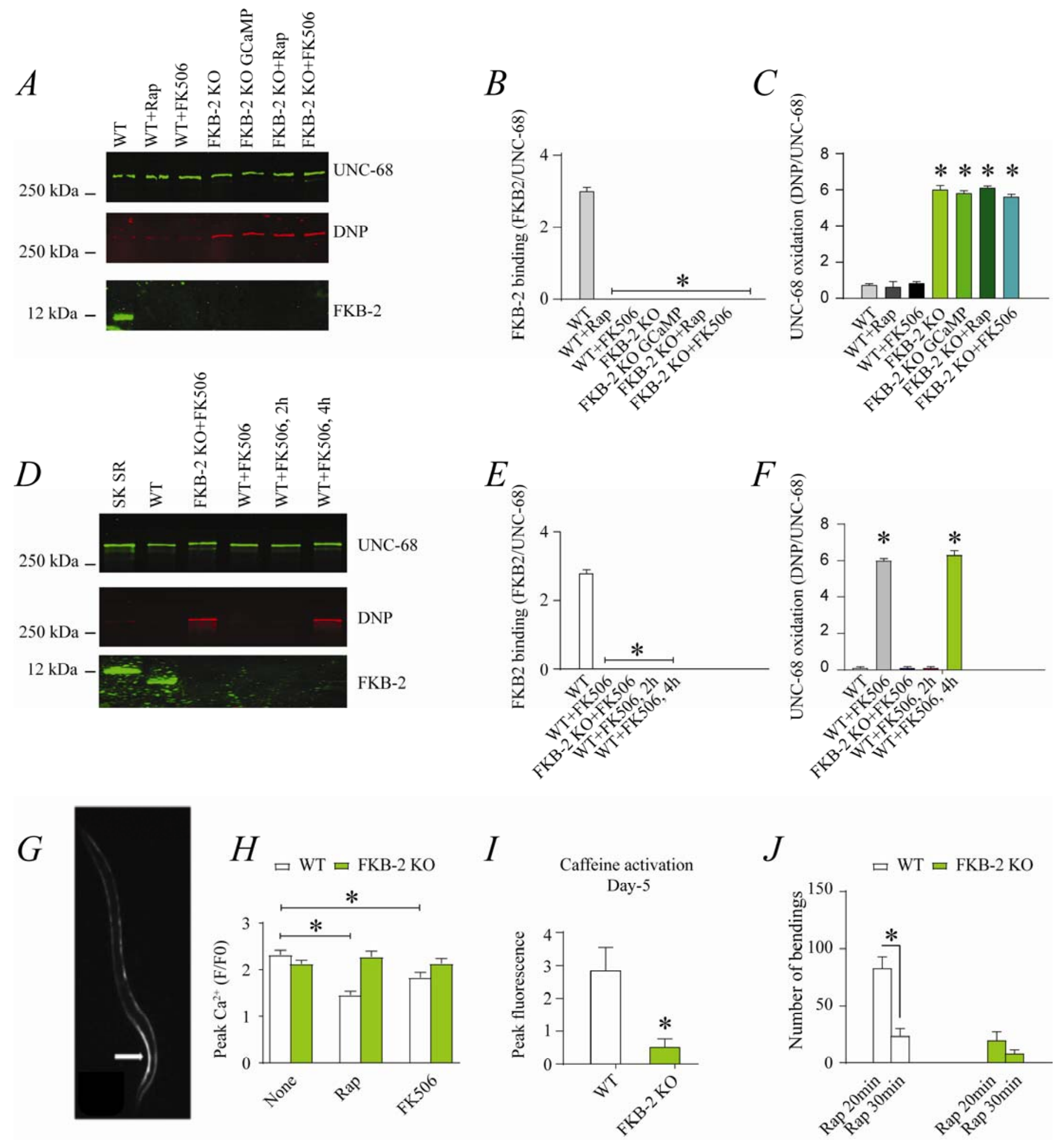

Figure 3: Depleting FKB-2 from UNC-68 causes UNC-68 oxidation (A) UNC-68 was immunoprecipitated and immunoblotted using anti-RyR, anti-Calstabin and DNP (marker of oxidation) antibodies in nematodes acutely treated with $15 \mu \mathrm{M}$ and $50 \mu \mathrm{M}$ rapamycin and FK506, respectively. (B-C) Quantification of the band intensity shown in (A): band intensity was defined as the ratio of either DNP (marker of UNC-68 oxidation) or FKB-2 binding over its corresponding /UNC-68's expression. (D) UNC-68 was immunoprecipitated after 2hrs, and 4 hrs FK506 exposure. Representative immunoblots from triplicate experiments. (E-F) Quantification of the band intensity shown in (D): band intensity was defined as the ratio 
of either DNP (marker of UNC-68 oxidation) or FKB-2 binding over its corresponding /UNC-68's expression. G) Representative image of caffeine activated calcium transient in GCaMP2 WT; arrow denotes peak fluorescence in body-wall muscle. $(\mathrm{H}) \mathrm{Ca}^{2+}$ transients in age-synchronized populations of wild type and FKB-2 (ok3007) nematodes treated with $15 \mu \mathrm{M}$ and $50 \mu \mathrm{M}$ rapamycin and FK506, respectively. (I) Fluorescence intensity following caffeine activation in age-matched GCaMP2: WT versus GCaMP2: FKB-2 KO worms at Day 5. (J) Graph showing number of bends recorded for WT vs FKB-2 KO worms (Day 5) treated for 20 and 30 minutes with $15 \mu \mathrm{M}$ and $50 \mu \mathrm{M}$ rapamycin and FK506, respectively. $\mathrm{N} \geq 15$ per group. Data are means \pm SEM. One-way ANOVA shows $* \mathrm{P}<0.05$ vs. WT for results shown in panel A to F. Twoway ANOVA was used for results comparison in panel $\mathrm{H}$ and t-test was used for results shown in I and $\mathrm{J}$. Sarcoplasmic reticulum fraction from mouse skeletal muscle. 

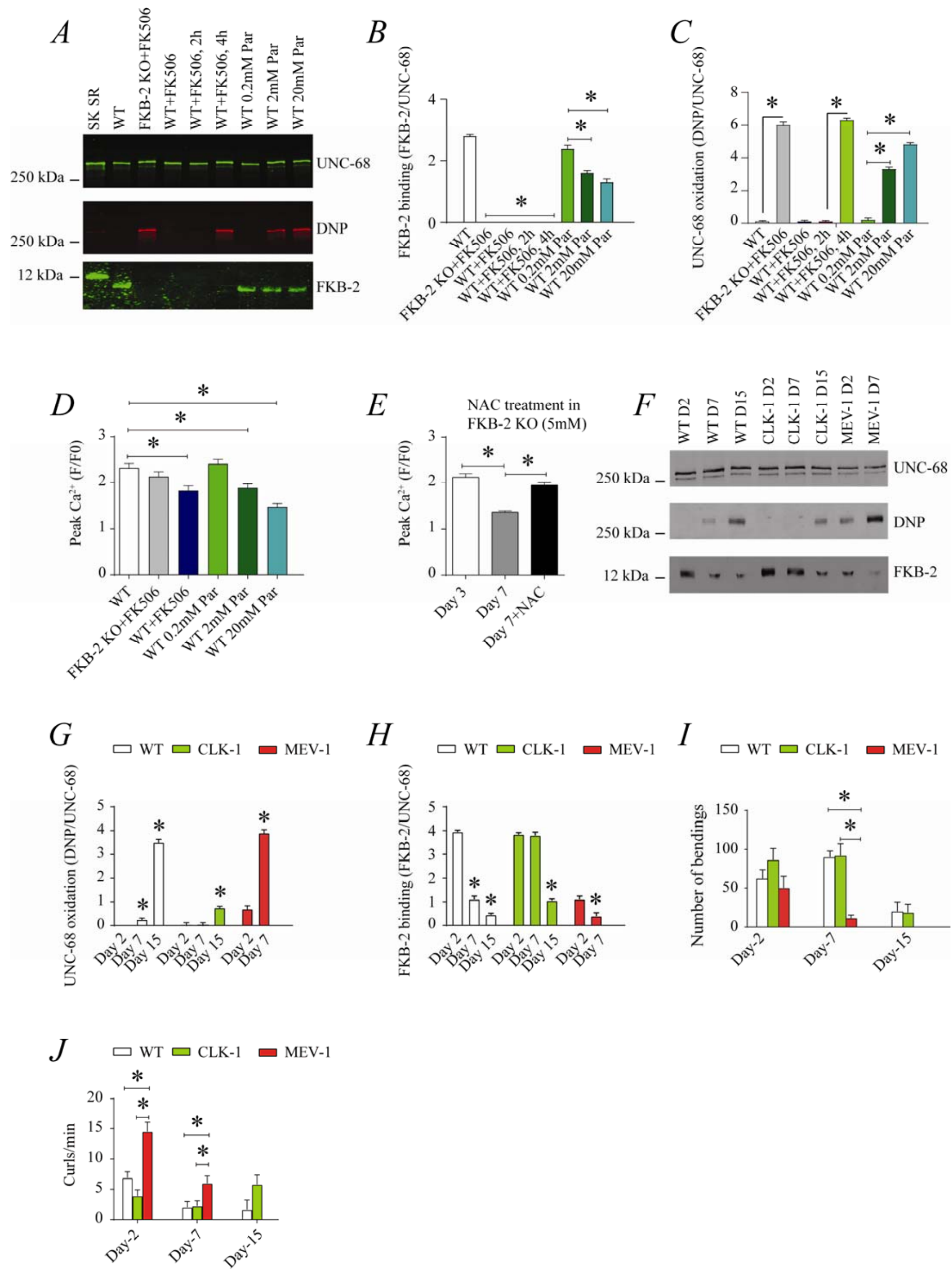
Figure 4: UNC-68 oxidation causes defective $\mathbf{C a}^{2+}$ handling; (A) UNC-68 was immunoprecipitated and immunoblotted using anti-RyR, anti-Calstabin and DNP (marker of oxidation) antibodies in nematodes acutely treated for 15-20 minutes with FK506 or paraquat at increasing concentration. (B-C) Quantification of the band intensity shown in (A): band intensity was defined as the ratio of either DNP (marker of UNC-68 oxidation) or FKB-2 binding over its corresponding/UNC-68's expression. (D) Contraction-associated $\mathrm{Ca}^{2+}$ transients measured in young age-synchronized WT nematodes treated for 15-20 minutes with increasing concentration of paraquat. (E) Contraction-associated $\mathrm{Ca}^{2+}$ transients measured in $\mathrm{FKB}-2 \mathrm{KO}$ nematodes treated with the antioxidant $\mathrm{N}$-acetylcysteine (NAC) at $5 \mathrm{mM}$. (F) UNC-68 was immunoprecipitated and immunoblotted using anti-RyR, anti-Calstabin and DNP (marker of oxidation) antibodies in WT, the long lived (CLK-1) and the short lived (MEV-1) nematodes at day 2, 7 and 15. (G-H) Quantification of the average band intensity from triplicate experiments: band intensity was defined as the ratio of each complex member's expression over its corresponding /UNC-68's expression. (I) Graph showing number of bends recorded for WT vs CLK-1 and MEV-1 worms at three distinct ages (Day 2, 7, 15). J) Number of curling events were calculated as a percentage of the overall motility (curls/bends). $\mathrm{N} \geq .20$ per group. Data are means \pm SEM. One-way ANOVA shows * $\mathrm{P}<0.05$. Two-way ANOVA was used in panel I and J. Sarcoplasmic reticulum fraction from mouse skeletal muscle. 

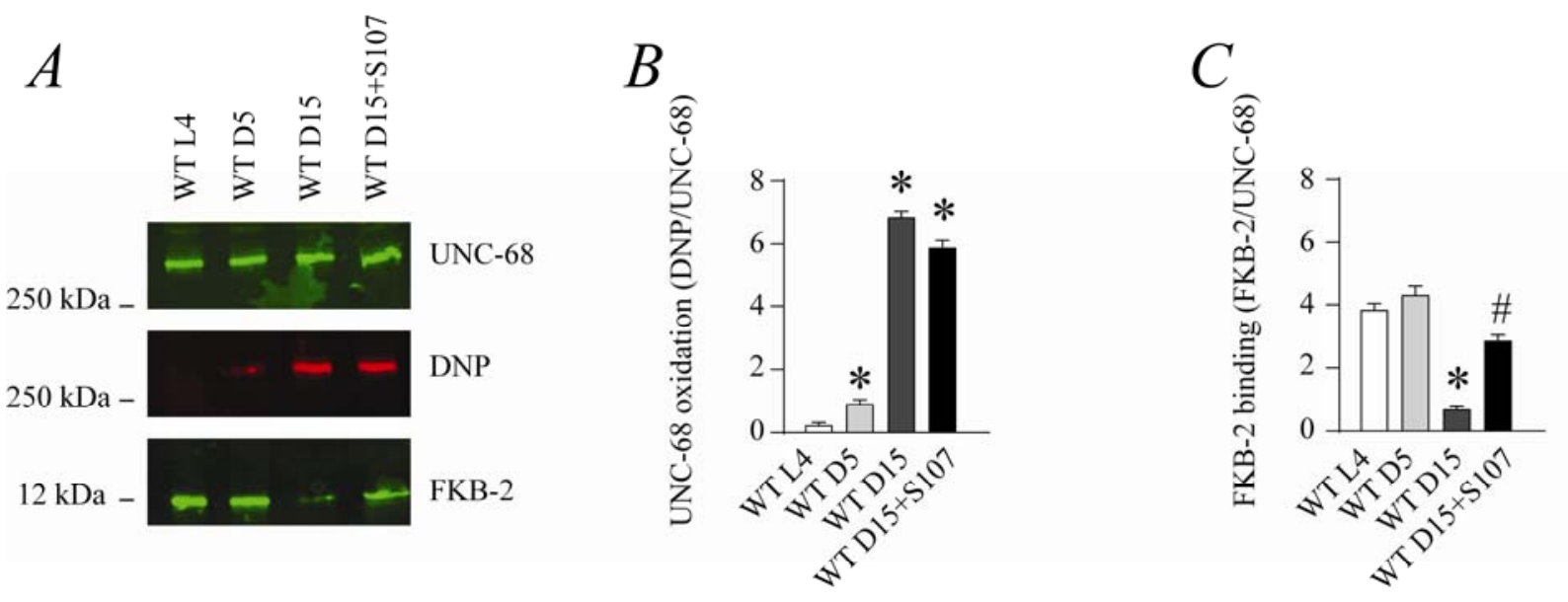

D $\quad 10 \mu \mathrm{M} \mathrm{S} 107$ treatment
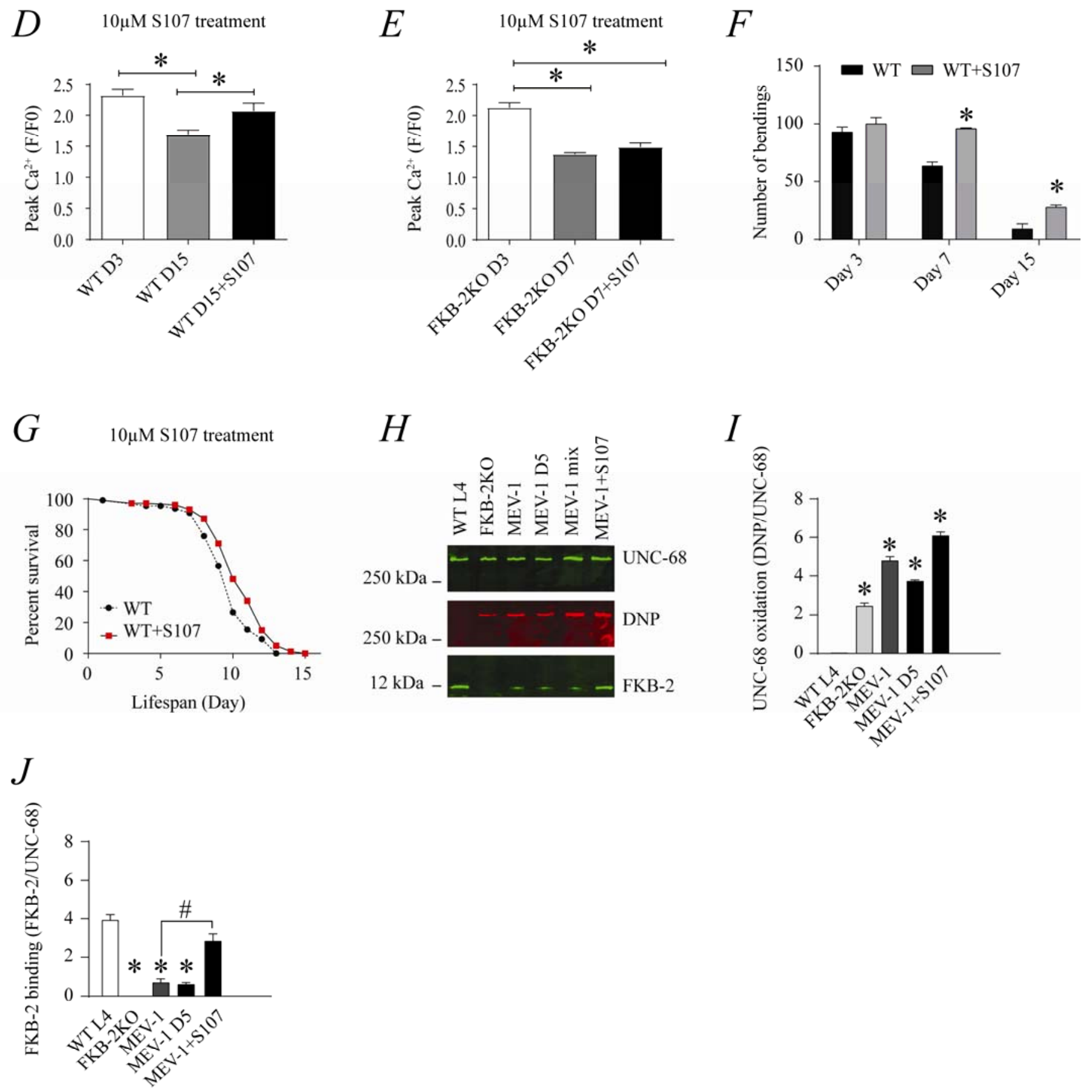
Figure 5: The RyR-stabilizing drug S107 increases body wall muscle $\mathrm{Ca}^{2+}$ transients in aged $\boldsymbol{C}$. elegans; (A) UNC-68 was immunoprecipitated and immunoblotted with anti-RyR, anti-Calstabin and DNP (marker of oxidation) in aged nematodes with $10 \mu \mathrm{M}$ of S107 (5hrs). (B-C) Quantification of the band intensity shown in (A): band intensity was defined as the ratio of either DNP (marker of $U N C$-68 oxidation) or FKB-2 binding over its corresponding /UNC-68's expression. Data are means \pm SEM. * $\mathrm{P}<0.05$ vs. WTL4, \# P<0.05 WT-D 15 vs. WT D15+S107. (D-E) Contraction-associated $\mathrm{Ca}^{2+}$ transients were measured in agesynchronized WT (D) and (E) fkb-2 (ok3007) treated with S107 as indicated. (F) Graph showing number of bends recorded for WT vs WT treated with S107 worms at different age (Day 3, 7, 15 days). (G) Percent of survival of WT vs WT treated with S107 nematodes. $(\mathrm{H})$ UNC-68 was immunoprecipitated and immunoblotted with anti-RyR, anti-Calstabin and DNP (marker of oxidation) in short-lived nematodes (MEV-1) with S107 treatment (3-5hrs). (I-J) Quantification of the band intensity shown in $(\mathrm{H})$ : band intensity was defined as the ratio of either DNP (marker of UNC-68 oxidation) or FKB-2 binding over its corresponding/UNC-68's expression. $\mathrm{N} \geq 20$ per group. Data are means \pm SEM. One-way ANOVA shows * $\mathrm{P}<0.05$ vs. In panel $\mathrm{F}$, a t-test was used to compare WT and WT+S107 for each day. WTL4 unless otherwise indicated. \#P<0.05 MEV-1, vs MEV-1+S107. 
bioRxiv preprint doi: https://doi.org/10.1101/2021.12.05.471286; this version posted December $6,2021$. The copyright holder for this preprint (which was not certified by peer review) is the author/funder. All rights reserved. No reuse allowed without permission.

Table S1: Oxidative regulators in $C$. elegans vs mice vs humans

\begin{tabular}{|c|c|c|c|c|c|c|}
\hline Protein & $\begin{array}{l}\text { FOXO } \\
\text { (Forkhead } \\
\text { Box Class } O)\end{array}$ & $\begin{array}{l}\text { CAT } \\
\text { (Catalase) }\end{array}$ & $\begin{array}{l}\text { SOD } \\
\text { (Superoxide } \\
\text { Dismutase) }\end{array}$ & $\begin{array}{l}\text { PRDX/PRX } \\
\text { (Peroxiredoxin) }\end{array}$ & TRX(Thioredoxin) & $\begin{array}{l}\text { GLRX } \\
\text { (Glutaredoxins) }\end{array}$ \\
\hline Function & $\begin{array}{l}\text { Transcription } \\
\text { Factor }\end{array}$ & $\begin{array}{l}\text { Antioxidative } \\
\text { Enzyme }\end{array}$ & $\begin{array}{l}\text { Antioxidative } \\
\text { Enzyme }\end{array}$ & $\begin{array}{l}\text { Antioxidative } \\
\text { Enzyme }\end{array}$ & $\begin{array}{l}\text { Antioxidative } \\
\text { Enzyme }\end{array}$ & $\begin{array}{l}\text { Antioxidative } \\
\text { Enzyme }\end{array}$ \\
\hline Human & FOXO1,3,4,6 & CAT & SOD1, 2, 3 & $\begin{array}{l}\text { PRDX/PRX } \\
1,2,3,4,5,6\end{array}$ & TRX & GLRX 1,2,3,5 \\
\hline Murine & FOXO1,3,4,6 & cat & Sod $1,2,3$ & $\operatorname{Prdx}$ & $\operatorname{Trx}$ & Glrx $1,2,3,5$ \\
\hline C. elegans & DAF-16 & Ctl 1, 2,3 & Sod $1,2,3,4,5$ & $\operatorname{prdx} 2,3,6$ & $\operatorname{trx} 1,2,3,4,5$ & glrx $3,5,10,21,22$ \\
\hline $\begin{array}{l}\text { Location } \\
\text { human vs } \\
\text { C. elegans }\end{array}$ & $\begin{array}{l}\text { Nucleus } \\
\text { Vs } \\
\text { Nucleus }\end{array}$ & $\begin{array}{l}\text { Peroxisome } \\
\text { vs } \\
\text { Peroxisome }\end{array}$ & $\begin{array}{l}\text { Cytoplasm, } \\
\text { nucleus and } \\
\text { mitochondria } \\
\text { vs cytoplasm } \\
\text { and } \\
\text { mitochondria }\end{array}$ & $\begin{array}{l}\text { Cytoplasm vs } \\
\text { cytoplasm }\end{array}$ & $\begin{array}{lr}\begin{array}{l}\text { Nucleus } \\
\text { cytoplasm }\end{array} & \text { and } \\
\text { nucleus } & \text { vs }\end{array}$ & $\begin{array}{l}\text { Cytoplasm, } \\
\text { mitochondria vs } \\
\text { mitochondrial matrix }\end{array}$ \\
\hline $\begin{array}{l}\text { Enzymatic } \\
\text { activity }\end{array}$ & None & 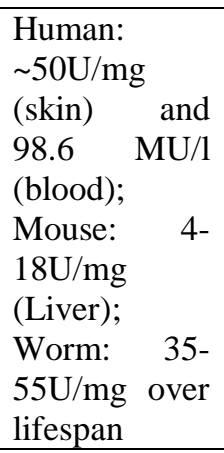 & $\begin{array}{l}\text { SOD-1 } \\
\text { Human: 30 } \\
\text { U/mg (skin) } \\
\text { Mouse: } 4 \\
\text { U/mg; SOD-2 }\end{array}$ & $\begin{array}{l}\text { Human \& Rat: } \\
40 \\
(\mathrm{mmol} / \mathrm{min} / \mathrm{mg})\end{array}$ & $\begin{array}{l}\text { Human: } \\
0.15 / 100 \text { ug x } 10^{\wedge} 3\end{array}$ & $\begin{array}{l}\text { Human:10nmol/min/ } \\
\text { mg in lung tissues } \\
\text { Mouse : Identical to } \\
\text { human }\end{array}$ \\
\hline $\begin{array}{l}\text { Disruption } \\
\text { phenotype } \\
\text { in } \\
\text { C. elegans }\end{array}$ & $\begin{array}{l}\text { Mouse: } \\
\text { Homozygote } \\
\text { has diverse } \\
\text { defects; } \\
\text { secondary } \\
\text { infertility, } \\
\text { decreased } \\
\text { glucose } \\
\text { uptake, mild } \\
\text { anemia. } \\
\text { Worm: } \\
\text { impaired } \\
\text { dauer } \\
\text { formation. }\end{array}$ & $\begin{array}{l}\text { Ctl2 KO } \\
\text { causes } \\
\text { progeria, } \\
\text { decreased } \\
\text { lifespan }\end{array}$ & $\begin{array}{l}\text { Overexpressi } \\
\text { on induces } \\
\text { resistance to } \\
\text { oxidative } \\
\text { stress and } \\
\text { increased } \\
\text { lifespan }\end{array}$ & $\begin{array}{ll}\text { Prdx-2 } & \text { KO } \\
\text { Worm: } & \\
\text { sensitive } & \text { to } \\
\text { oxidation. } & \\
\text { decreased } & \\
\text { lifespan. } & \end{array}$ & $\begin{array}{lr}\text { Trx ko } & \text { worms: } \\
\text { reduced } & \text { lifespan, } \\
\text { sensitive } & \text { to } \\
\text { oxidative } & \text { stress } \\
\text { (paraquat) } & \end{array}$ & Not tested \\
\hline Homology & $\begin{array}{l}22.14 \% \quad \text { ID, } \\
\text { (to FOXO3) }\end{array}$ & $\begin{array}{l}60.53 \text { ID to } \\
\text { clt1 }\end{array}$ & $\begin{array}{l}55.35 \\
\text { SOD1 }\end{array}$ & $\begin{array}{lll}72.86 & \text { ID } & \text { to } \\
\text { prdx } 6 & & \end{array}$ & $33.91 \%$ ID to trx 1 & $45.10 \%$ ID to glrx3 \\
\hline References & $(90,91)$ & (92) & (93) & $(94,95)$ & $(96-98)$ & (99) \\
\hline
\end{tabular}


bioRxiv preprint doi: https://doi.org/10.1101/2021.12.05.471286; this version posted December $6,2021$. The copyright holder for this preprint (which was not certified by peer review) is the author/funder. All rights reserved. No reuse allowed without permission.

\begin{tabular}{|c|c|c|c|c|c|c|}
\hline Protein & $\begin{array}{l}\text { Glutathione } \\
\text { S-transferase }\end{array}$ & $\begin{array}{l}\text { NAD- } \\
\text { dependent } \\
\text { protein } \\
\text { deacetylase } \\
(\text { SIR })\end{array}$ & $\begin{array}{l}\text { Dual } \\
\text { specificity } \\
\text { mitogen- } \\
\text { activated } \\
\text { protein kinase } \\
\text { kinase }\end{array}$ & $\begin{array}{l}\text { Nuclear } \\
\text { respiratory } \\
\text { factor } 1 \\
\text { (NRF1) }\end{array}$ & $\begin{array}{l}\text { Dual } \\
\text { oxidase } 1\end{array}$ & $\begin{array}{l}\text { D-beta- } \\
\text { hydroxybutyrate } \\
\text { dehydrogenase }\end{array}$ \\
\hline Function & $\begin{array}{l}\text { Antioxidative } \\
\text { Enzyme }\end{array}$ & $\begin{array}{l}\text { reduction of } \\
\text { the 'Lys-16' } \\
\text { acetylation of } \\
\text { histone H4 }\end{array}$ & $\begin{array}{l}\text { Kinase } \\
\text { activity } \\
\text { involved in } \\
\text { oxidative } \\
\text { stress }\end{array}$ & $\begin{array}{l}\text { mitochondrial } \\
\text { DNA } \\
\text { transcription } \\
\text { and replication }\end{array}$ & N/A & $\begin{array}{l}\text { Oxidative } \\
\text { Enzyme }\end{array}$ \\
\hline Human & $\begin{array}{l}\text { GSTA 1-5/ } \\
\text { GSTM 1-5 }\end{array}$ & SIRT 1-7 & MAP2K1 & NRF1 & $\begin{array}{l}\text { Oxidative } \\
\text { Enzyme }\end{array}$ & BDH1 \\
\hline Murine & $\begin{array}{l}\text { GSTA 1-7/ } \\
\text { Gstm 1-4 }\end{array}$ & Sir 1-7 & & Nfr1 & DUOX1 & Bdh1 \\
\hline C. elegans & Gst 1-44 & Sir 2.1-2.4 & Mek 1, 2 & Skn 1 & Duox1 & N/A \\
\hline $\begin{array}{l}\text { Location } \\
\text { human vs } \\
\text { C. elegans }\end{array}$ & $\begin{array}{l}\text { Cytosol vs } \\
\text { Cytoplasm and } \\
\text { mitochondria }\end{array}$ & $\begin{array}{l}\text { Nucleus, } \\
\text { mitochondria } \\
\text { and cytoplasm } \\
\text { vs } \\
\text { Nucleus and } \\
\text { cytoplasm }\end{array}$ & $\begin{array}{l}\text { Nucleus and } \\
\text { mitochondria } \\
\text { vs Cytoplasm }\end{array}$ & $\begin{array}{l}\text { cytoplasm vs } \\
\text { Nucleus and } \\
\text { mitochondria }\end{array}$ & bli-3 & Mitochondria \\
\hline $\begin{array}{l}\text { Enzymatic } \\
\text { activity }\end{array}$ & $\begin{array}{l}121 \\
\mathrm{nmol} / \mathrm{min} / \mathrm{mg} \\
\text { in human } \\
\text { N/A for C- } \\
\text { elegans }\end{array}$ & N/A & N/A & N/A & $\begin{array}{l}\text { Plasma } \\
\text { membrane vs } \\
\text { plasma } \\
\text { membrane }\end{array}$ & N/A \\
\hline $\begin{array}{l}\text { Disruption } \\
\text { phenotype } \\
\text { in } \\
\text { C. elegans }\end{array}$ & $\begin{array}{l}\text { RNAi- } \\
\text { mediated } \\
\text { knockdown } \\
\text { causes an } \\
\text { increase in } \\
\mathrm{Mn}^{2+} \text { - } \\
\text { mediated } \\
\text { dopaminergic } \\
\text { CEP neuron } \\
\text { degeneration }\end{array}$ & $\begin{array}{l}\text { Reduces the } \\
\text { longevity } \\
\text { RNAi- } \\
\text { mediated } \\
\text { depletion } \\
\text { results in an } \\
\text { increase of } \\
\text { 'Lys-16' } \\
\text { acetylation of } \\
\text { histone H4 } \\
\text { (H4K16ac) }\end{array}$ & $\begin{array}{l}\text { defects in egg } \\
\text { laying } \\
\text { infertility } \\
\text { Reduced } \\
\text { lifespan with } \\
\text { stress. } \\
\text { No obvious } \\
\text { phenotype in } \\
\text { absence of } \\
\text { stress }\end{array}$ & $\begin{array}{l}\text { RNAi- } \\
\text { mediated } \\
\text { knockdown } \\
\text { causes an } \\
\text { increase in } \\
\mathrm{Mn}^{2+} \text { - } \\
\text { mediated } \\
\text { dopaminergic } \\
\text { CEP neuron } \\
\text { degeneration } \\
\text { and a } \\
\text { reduction in } \\
\text { expression } \\
\text { levels } \\
\text { glutathione } \quad \mathrm{S} \text { - } \\
\text { transferase } \\
\text { gst-1 }\end{array}$ & $\begin{array}{l}\text { RNAi- } \\
\text { mediated } \\
\text { knockdown } \\
+\quad \text { proline } \\
\text { ROS } \\
\text { production, } \\
\text { reduces the } \\
\text { expression of } \\
\text { skn-1 and } \\
\text { reduces } \\
\text { longevity }\end{array}$ & $\mathrm{N} / \mathrm{A}$ \\
\hline Homology & $\begin{array}{l}29.28 \% \text { ID to } \\
\text { GSTA1 }\end{array}$ & $\begin{array}{l}28.17 \% \text { ID to } \\
\text { SIR1 }\end{array}$ & & $\begin{array}{l}12.20 \% \text { ID to } \\
\text { NRF1 }\end{array}$ & $32.78 \%$ & $\mathrm{~N} / \mathrm{A}$ \\
\hline Refs & $(100,101)$ & $(102-104)$ & & $\begin{array}{ll}(101, & 105, \\
106) & \end{array}$ & $(107,108)$ & \\
\hline
\end{tabular}




\begin{tabular}{|c|c|c|c|c|c|}
\hline Protein & $\begin{array}{l}\text { Xanthine } \\
\text { Oxidase }\end{array}$ & NO Synthase & $\begin{array}{l}\text { Cytochrome } \\
\text { P450 }\end{array}$ & $\begin{array}{l}\text { Hydroxyacid } \\
\text { oxidase } 1\end{array}$ & $\begin{array}{l}\text { SDH (Succinate } \\
\text { Dehydrogenase) }\end{array}$ \\
\hline Function & $\begin{array}{l}\text { Oxidative } \\
\text { Enzyme }\end{array}$ & $\begin{array}{l}\text { Oxidative } \\
\text { Enzyme }\end{array}$ & $\begin{array}{l}\text { Oxidative } \\
\text { Enzyme }\end{array}$ & $\begin{array}{l}\text { Oxidative } \\
\text { Enzyme }\end{array}$ & $\begin{array}{l}\text { Oxidative } \\
\text { Enzyme }\end{array}$ \\
\hline Human & $\mathrm{XDH}$ & NOS $1,2,3$ & $\begin{array}{l}\text { CYP } \\
\text { (Multiple) }\end{array}$ & HAO1 & $\begin{array}{l}\text { SDHA, SDHB, } \\
\text { SDHC, SDHD }\end{array}$ \\
\hline Murine & $\mathrm{Xdh}$ & Nos $1,2,3$ & $\begin{array}{l}\text { Cyp } \\
\text { (multiple) }\end{array}$ & Hao1 & $\begin{array}{l}\text { Sdha, Sdhb, Sdhc, } \\
\text { Sdhd }\end{array}$ \\
\hline C. elegans & xdh-1 & Unknown & сур-(23-37) & Unknown & $\begin{array}{l}\text { sdha-1, } \text { sdhb-1, } \\
\text { sdhd-1 }\end{array}$ \\
\hline $\begin{array}{l}\text { Location } \\
\text { human vs } \\
\text { C. elegans }\end{array}$ & $\begin{array}{l}\text { Peroxisome } \\
\text { and } \\
\text { Extracellular } \\
\text { region vs } \\
\text { Cytosol }\end{array}$ & & $\begin{array}{l}\text { ER vs } \\
\text { Unknown }\end{array}$ & & $\begin{array}{l}\text { Mitochondria VS } \\
\text { Mitochondria }\end{array}$ \\
\hline $\begin{array}{l}\text { Enzymatic } \\
\text { activity }\end{array}$ & $\begin{array}{l}\text { Rat: } 4.4 \mathrm{ccm} \\
\text { oxy } \\
\text { uptake/unit } \\
\text { time/unit } \\
\text { weight of } \\
\text { intestine }\end{array}$ & $\begin{array}{l}\text { Human: } .5-2.5 \\
\text { pmol/min/mg } \\
\text { (brain) Mouse: } \\
\text { Normalized to } \\
1\end{array}$ & Multiple & --- & $\begin{array}{l}1.45 \text { ferricyanide } \\
\text { reduced/min.mg } \\
\text { wetwt. } \\
\text { (Euthyroid) }\end{array}$ \\
\hline $\begin{array}{l}\text { Disruption } \\
\text { phenotype } \\
\text { in } \\
\text { C. elegans }\end{array}$ & Unavailable & & Unavailable & & Unavailable \\
\hline Homology & $46.54 \%$ & & $28.97 \%$ & & $69.12 \%$ \\
\hline Refs & $(109)$ & & $(110-113)$ & & (114) \\
\hline
\end{tabular}


Table S2: Amino acid composition of UNC-68 and Human RyR1

\begin{tabular}{|c|c|c|c|c|}
\hline \multirow{2}{*}{$\begin{array}{l}\text { UNC-68 (C. elegans) } \\
\text { Number of amino acids }\end{array}$} & \multirow[b]{2}{*}{5187} & & \multicolumn{2}{|l|}{ RyR1 (Human) } \\
\hline & & & 5038 & \\
\hline Molecular weight & 589102.13 & & 565175.53 & \\
\hline Amino acid composition: & Number & $\%$ & Number & $\%$ \\
\hline Ala (A) & 333 & 6.4 & 384 & 7.6 \\
\hline $\operatorname{Arg}(\mathrm{R})$ & 265 & 5.1 & 294 & 5.8 \\
\hline $\operatorname{Asn}(\mathrm{N})$ & 216 & 4.2 & 170 & 3.4 \\
\hline Asp (D) & 302 & 5.8 & 253 & 5 \\
\hline Cys (C) & 90 & 1.7 & 100 & 2 \\
\hline $\mathrm{Gln}(\mathrm{Q})$ & 235 & 4.5 & 205 & 4.1 \\
\hline Glu (E) & 417 & 8 & 476 & 9.4 \\
\hline Gly $(\mathrm{G})$ & 305 & 5.9 & 363 & 7.2 \\
\hline His $(\mathrm{H})$ & 133 & 2.6 & 133 & 2.6 \\
\hline Ile (I) & 281 & 5.4 & 203 & 4 \\
\hline Leu (L) & 533 & 10.3 & 558 & 11.1 \\
\hline Lys $(\mathrm{K})$ & 314 & 6.1 & 228 & 4.5 \\
\hline Met (M) & 179 & 3.5 & 145 & 2.9 \\
\hline Phe (F) & 251 & 4.8 & 207 & 4.1 \\
\hline Pro $(\mathrm{P})$ & 194 & 3.7 & 271 & 5.4 \\
\hline Ser $(\mathbf{S})$ & 376 & 7.2 & 296 & 5.9 \\
\hline Thr (T) & 256 & 4.9 & 231 & 4.6 \\
\hline $\operatorname{Trp}(\mathrm{W})$ & 61 & 1.2 & 63 & 1.3 \\
\hline Tyr (Y) & 155 & 3 & 141 & 2.8 \\
\hline Val (V) & 291 & 5.6 & 317 & 6.3 \\
\hline Pyl (O) & 0 & 0 & 0 & 0 \\
\hline $\operatorname{Sec}(\mathrm{U})$ & 0 & 0 & 0 & 0 \\
\hline
\end{tabular}




\section{References}

1. Marzetti E \& Leeuwenburgh C (2006) Skeletal muscle apoptosis, sarcopenia and frailty at old age. Exp Gerontol 41(12):1234-1238.

2. Ganz DA, Bao Y, Shekelle PG, \& Rubenstein LZ (2007) Will my patient fall? JAMA 297(1):77-86.

3. Santulli G, Ciccarelli M, Trimarco B, \& Iaccarino G (2013) Physical activity ameliorates cardiovascular health in elderly subjects: the functional role of the beta adrenergic system. Front Physiol 4:209.

4. Herndon LA, et al. (2002) Stochastic and genetic factors influence tissue-specific decline in ageing C. elegans. Nature 419(6909):808-814.

5. Ljubuncic P \& Reznick AZ (2009) The evolutionary theories of aging revisited--a mini-review. Gerontology 55(2):205-216.

6. Guarente L \& Kenyon C (2000) Genetic pathways that regulate ageing in model organisms. Nature 408(6809):255-262.

7. $\quad$ Kenyon CJ (2010) The genetics of ageing. Nature 464(7288):504-512.

8. Hsu AL, Feng Z, Hsieh MY, \& Xu XZ (2009) Identification by machine vision of the rate of motor activity decline as a lifespan predictor in C. elegans. Neurobiol Aging 30(9):1498-1503.

9. Liu J, et al. (2013) Functional Aging in the Nervous System Contributes to Age-Dependent Motor Activity Decline in C. elegans. Cell Metab 18(3):392-402.

10. Kirkwood TB (2013) Untangling functional declines in the locomotion of aging worms. Cell Metab 18(3):303-304.

11. Zalk R.; Clarke O.B.; des Georges A.; Grassucci R.A.; Reiken S.; Mancia F.; Hendrickson W.A.; Frank J. MAR (2015) Structure of a mammalian ryanodine receptor. Nature 517(7532):44-49.

12. Zalk R, et al. (2015) Structure of a mammalian ryanodine receptor. Nature 517(7532):44-49.

13. Gonzalez E, Messi ML, Zheng ZL, \& Delbono 0 (2003) Insulin-like growth factor-1 prevents agerelated decrease in specific force and intracellular $\mathrm{Ca} 2+$ in single intact muscle fibres from transgenic mice. Journal of Physiology-London 552(3):833-844.

14. Jimenez-Moreno R, Wang ZM, Gerring RC, \& Delbono 0 (2008) Sarcoplasmic reticulum Ca2+ release declines in muscle fibers from aging mice. Biophysical Journal 94(8):3178-3188.

15. Andersson DC, et al. (2011) Ryanodine receptor oxidation causes intracellular calcium leak and muscle weakness in aging. Cell Metab 14(2):196-207.

16. Umanskaya A, et al. (2014) Genetically enhancing mitochondrial antioxidant activity improves muscle function in aging. Proc Natl Acad Sci U S A in press.

17. Zalk R, Lehnart SE, \& Marks AR (2007) Modulation of the ryanodine receptor and intracellular calcium. Annu Rev Biochem 76:367-385.

18. Marx S0, et al. (2000) PKA phosphorylation dissociates FKBP12.6 from the calcium release channel (ryanodine receptor): defective regulation in failing hearts. Cell 101(4):365-376.

19. Kass RS, Kurokawa J, Marx S0, \& Marks AR (2003) Leucine/isoleucine zipper coordination of ion channel macromolecular signaling complexes in the heart. Roles in inherited arrhythmias. Trends Cardiovasc Med 13(2):52-56.

20. Lehnart SE, et al. (2005) Phosphodiesterase 4D deficiency in the ryanodine-receptor complex promotes heart failure and arrhythmias. Cell 123(1):25-35.

21. Currie S, Loughrey CM, Craig MA, \& Smith GL (2004) Calcium/calmodulin-dependent protein kinase IIdelta associates with the ryanodine receptor complex and regulates channel function in rabbit heart. Biochem J 377(Pt 2):357-366.

22. Kushnir A, Shan J, Betzenhauser MJ, Reiken S, \& Marks AR (2010) Role of CaMKIIdelta phosphorylation of the cardiac ryanodine receptor in the force frequency relationship and heart failure. Proc Natl Acad Sci U S A 107(22):10274-10279. 
23. Bellinger AM, et al. (2008) Remodeling of ryanodine receptor complex causes "leaky" channels: a molecular mechanism for decreased exercise capacity. Proc Natl Acad Sci U S A 105(6):21982202.

24. Santulli G \& Marks AR (2015) Essential roles of intracellular calcium release channels in muscle, brain, metabolism, and aging. Current Molecular Pharmacology In press.

25. Anonymous (!!! INVALID CITATION !!! \{Marx, 2000 \#18;Brillantes, 1994 \#67;Jayaraman, 1992 \#87;Marx, 2000 \#34\}).

26. Marks AR (1996) Cellular functions of immunophilins. Physiol Rev 76(3):631-649.

27. Brillantes AB, et al. (1994) Stabilization of calcium release channel (ryanodine receptor) function by FK506-binding protein. Cell 77(4):513-523.

28. Harnick DJ, et al. (1995) The human type 1 inositol 1,4,5-trisphosphate receptor from $\mathrm{T}$ lymphocytes. Structure, localization, and tyrosine phosphorylation. J Biol Chem 270(6):28332840.

29. Jayaraman T, Ondriasova E, Ondrias K, Harnick DJ, \& Marks AR (1995) The inositol 1,4,5trisphosphate receptor is essential for T-cell receptor signaling. Proc Natl Acad Sci USA 92(13):6007-6011.

30. Jayaraman T \& Marks AR (2000) Calcineurin is downstream of the inositol 1,4,5-trisphosphate receptor in the apoptotic and cell growth pathways. J Biol Chem 275(9):6417-6420.

31. D.I. AKJS-PACRWLR-TIY (2015) Tracing the Evolutionary History of Inositol, 1, 4, 5Trisphosphate Receptor: Insights from Analyses of Capsaspora owczarzaki Ca2+ Release Channel Orthologs. Mol Biol Evol 32(9):2236-2253.

32. A.R. DNRSOKYYMSM (2002) Protein kinase A and two phosphatases are components of the inositol 1,4,5-trisphosphate receptor macromolecular signaling complex. J Biol Chem (277):39397-39400.

33. Dridi $\mathrm{H}$, et al. (2020) Intracellular calcium leak in heart failure and atrial fibrillation: a unifying mechanism and therapeutic target. Nat Rev Cardiol.

34. Marks AR (2003) A guide for the perplexed: towards an understanding of the molecular basis of heart failure. Circulation 107(11):1456-1459.

35. Lehnart SE, et al. (2006) Stabilization of cardiac ryanodine receptor prevents intracellular calcium leak and arrhythmias. Proc Natl Acad Sci U S A 103(20):7906-7910.

36. Lehnart SE, et al. (2004) Sudden death in familial polymorphic ventricular tachycardia associated with calcium release channel (ryanodine receptor) leak. Circulation 109(25):32083214.

37. Vest JA, et al. (2005) Defective cardiac ryanodine receptor regulation during atrial fibrillation. Circulation 111(16):2025-2032.

38. Wehrens XH, et al. (2003) FKBP12.6 deficiency and defective calcium release channel (ryanodine receptor) function linked to exercise-induced sudden cardiac death. Cell 113(7):829-840.

39. Santulli G, et al. (2015) Calcium release channel RyR2 regulates insulin release and glucose homeostasis. J Clin Invest 125(11):4316.

40. Kushnir A, et al. (2020) Intracellular calcium leak as a therapeutic target for RYR1-related myopathies. Acta Neuropathol 139(6):1089-1104.

41. Dridi $\mathrm{H}$, et al. (2020) Role of defective calcium regulation in cardiorespiratory dysfunction in Huntington's disease. JCI Insight.

42. Matecki S, et al. (2016) Leaky ryanodine receptors contribute to diaphragmatic weakness during mechanical ventilation. Proc Natl Acad Sci U S A 113(32):9069-9074.

43. Dridi H, et al. (2020) Mitochondrial oxidative stress induces leaky ryanodine receptor during mechanical ventilation. Free Radic Biol Med 146:383-391. 
44. Lacampagne A, et al. (2017) Post-translational remodeling of ryanodine receptor induces calcium leak leading to Alzheimer's disease-like pathologies and cognitive deficits. Acta Neuropathol 134(5):749-767.

45. Liu X, et al. (2012) Role of leaky neuronal ryanodine receptors in stress-induced cognitive dysfunction. Cell 150(5):1055-1067.

46. des Georges A, et al. (2016) Structural Basis for Gating and Activation of RyR1. Cell 167(1):145157 e117.

47. M.G. CYTHSNNCKYPPBPGDAFC (2009) A dihydropyridine receptor alpha1s loop region critical for skeletal muscle contraction is intrinsically unstructured and binds to a SPRY domain of the type 1 ryanodine receptor. Int J Biochem Cell Biol (41):677-686.

48. Maryon EB, Coronado R, \& Anderson P (1996) unc-68 encodes a ryanodine receptor involved in regulating C. elegans body-wall muscle contraction. J Cell Biol 134(4):885-893.

49. Marques F, et al. (2020) Tissue-specific isoforms of the single C. elegans Ryanodine receptor gene unc-68 control specific functions. PLoS Genet 16(10):e1009102.

50. Brenner S (1974) The genetics of Caenorhabditis elegans. Genetics 77(1):71-94.

51. Sakube $Y$, Ando H, \& Kagawa H (1997) An abnormal ketamine response in mutants defective in the ryanodine receptor gene ryr-1 (unc-68) of Caenorhabditis elegans. J Mol Biol 267(4):849864.

52. Timerman AP, et al. (1993) The calcium release channel of sarcoplasmic reticulum is modulated by FK-506-binding protein. Dissociation and reconstitution of FKBP-12 to the calcium release channel of skeletal muscle sarcoplasmic reticulum. J Biol Chem 268(31):22992-22999.

53. Lee SS, et al. (2003) A systematic RNAi screen identifies a critical role for mitochondria in C. elegans longevity. Nat Genet 33(1):40-48.

54. Kushnir A, et al. (2018) Ryanodine Receptor Calcium Leak in Circulating B-Lymphocytes as a Biomarker in Heart Failure. Circulation 138(11):1144-1154.

55. Charlie NK, Thomure AM, Schade MA, \& Miller KG (2006) The Dunce cAMP phosphodiesterase PDE-4 negatively regulates $G$ alpha(s)-dependent and $G$ alpha(s)-independent cAMP pools in the Caenorhabditis elegans synaptic signaling network. Genetics 173(1):111-130.

56. Bellinger AM, et al. (2009) Hypernitrosylated ryanodine receptor calcium release channels are leaky in dystrophic muscle. Nat Med 15(3):325-330.

57. Allen DG, Lamb GD, \& Westerblad H (2008) Skeletal muscle fatigue: cellular mechanisms. Physiol Rev 88(1):287-332.

58. Degens H (2007) Age-related skeletal muscle dysfunction: causes and mechanisms. J Musculoskelet Neuronal Interact 7(3):246-252.

59. Liu XB, M.J.; Reiken, S.; Meli, A.C.; Xie, W.; Chen, B.X.; Arancio, O.; Marks, A.R. (2012) Role of leaky neuronal ryanodine receptors in stress-induced cognitive dysfunction. Cell 150(5):10551067.

60. Andersson DC, et al. (2012) Stress-induced increase in skeletal muscle force requires protein kinase A phosphorylation of the ryanodine receptor. J Physiol 590(24):6381-6387.

61. F. LKFUGDCD (2014) Gait-specific adaptation of locomotor activity in response to dietary restriction in Caenorhabditis elegans. J Exp Biol. 217(Pt.14):2480-2488.

62. Ahern GP, Junankar PR, \& Dulhunty AF (1997) Subconductance states in single-channel activity of skeletal muscle ryanodine receptors after removal of FKBP12. Biophysical Journal 72(1):146162.

63. Santulli G \& Totary-Jain H (2013) Tailoring mTOR-based therapy: molecular evidence and clinical challenges. Pharmacogenomics 14(12):1517-1526.

64. Tallini YN, et al. (2006) Imaging cellular signals in the heart in vivo: Cardiac expression of the high-signal Ca2+ indicator GCaMP2. Proceedings of the National Academy of Sciences of the United States of America 103(12):4753-4758. 
65. Liu P, et al. (2011) Genetic dissection of ion currents underlying all-or-none action potentials in C. elegans body-wall muscle cells. J Physiol 589(Pt 1):101-117.

66. Yang YY, et al. (2011) The role of DMQ(9) in the long-lived mutant clk-1. Mech Ageing Dev 132(6-7):331-339.

67. Labuschagne CF, et al. (2013) Quantification of in vivo oxidative damage in Caenorhabditis elegans during aging by endogenous F3-isoprostane measurement. Aging Cell 12(2):214-223.

68. Kayser EB, Sedensky MM, \& Morgan PG (2004) The effects of complex I function and oxidative damage on lifespan and anesthetic sensitivity in Caenorhabditis elegans. Mech Ageing Dev 125(6):455-464.

69. Ishii $\mathrm{N}$, et al. (1998) A mutation in succinate dehydrogenase cytochrome b causes oxidative stress and ageing in nematodes. Nature 394(6694):694-697.

70. Senoo-Matsuda N, et al. (2001) A defect in the cytochrome b large subunit in complex II causes both superoxide anion overproduction and abnormal energy metabolism in Caenorhabditis elegans. J Biol Chem 276(45):41553-41558.

71. Senoo-Matsuda N, Hartman PS, Akatsuka A, Yoshimura S, \& Ishii N (2003) A complex II defect affects mitochondrial structure, leading to ced-3- and ced-4-dependent apoptosis and aging. $J$ Biol Chem 278(24):22031-22036.

72. Lehnart SE, et al. (2008) Leaky Ca2+ release channel/ryanodine receptor 2 causes seizures and sudden cardiac death in mice. J Clin Invest 118(6):2230-2245.

73. Hagen TM (2003) Oxidative stress, redox imbalance, and the aging process. Antioxidants \& redox signaling 5(5):503-506.

74. Harman D (1956) Aging: a theory based on free radical and radiation chemistry. Journal of gerontology 11(3):298-300.

75. Gems D \& Doonan R (2009) Antioxidant defense and aging in C. elegans: is the oxidative damage theory of aging wrong? Cell Cycle 8(11):1681-1687.

76. Van Raamsdonk JM \& Hekimi S (2012) Superoxide dismutase is dispensable for normal animal lifespan. Proc Natl Acad Sci U S A 109(15):5785-5790.

77. Yang YL, et al. (2013) SESN-1 is a positive regulator of lifespan in Caenorhabditis elegans. Exp Gerontol 48(3):371-379.

78. Back P, et al. (2012) Exploring real-time in vivo redox biology of developing and aging Caenorhabditis elegans. Free Radic Biol Med 52(5):850-859.

79. Shields HJ, Traa A, \& Van Raamsdonk JM (2021) Beneficial and Detrimental Effects of Reactive Oxygen Species on Lifespan: A Comprehensive Review of Comparative and Experimental Studies. Front Cell Dev Biol 9:628157.

80. Wilkinson DJ, Piasecki M, \& Atherton PJ (2018) The age-related loss of skeletal muscle mass and function: Measurement and physiology of muscle fibre atrophy and muscle fibre loss in humans. Ageing Res Rev 47:123-132.

81. Schanzenbach DW, Nunn R, \& Bauer L (2016) The changing landscape of American life expectancy. Washington, DC: The Hamilton Project, June.

82. Andersson DC, et al. (2011) Ryanodine receptor oxidation causes intracellular calcium leak and muscle weakness in aging. Cell Metabolism 14(2):196-207.

83. Porta-de-la-Riva M, Fontrodona L, Villanueva A, \& Ceron J (2012) Basic Caenorhabditis elegans methods: synchronization and observation. J Vis Exp (64):e4019.

84. Mitchell DH, Stiles JW, Santelli J, \& Sanadi DR (1979) Synchronous growth and aging of Caenorhabditis elegans in the presence of fluorodeoxyuridine. J Gerontol 34(1):28-36.

85. Francis GR \& Waterston RH (1985) Muscle organization in Caenorhabditis elegans: localization of proteins implicated in thin filament attachment and I-band organization. $J$ Cell Biol 101(4):1532-1549. 
86. Jayaraman T, et al. (1992) FK506 binding protein associated with the calcium release channel (ryanodine receptor). J Biol Chem 267(14):9474-9477.

87. Xie W, et al. (2013) Imaging atrial arrhythmic intracellular calcium in intact heart. J Mol Cell Cardiol 64:120-123.

88. Yuan Q et al. (2014) Functional Role of Calstabin2 in Age-related Cardiac Alterations. Sci Rep 4:7425.

89. A. WMKXWQZCMCP (2017) Regulator of G protein signaling-1 modulates paraquat-induced oxidative stress and longevity via the insulin like signaling pathway in Caenorhabditis elegans. Toxicology Letters (273):97-105.

90. Lehtinen MK, et al. (2006) A conserved MST-FOXO signaling pathway mediates oxidative-stress responses and extends life span. Cell 125(5):987-1001.

91. Lee RY, Hench J, \& Ruvkun G (2001) Regulation of C. elegans DAF-16 and its human ortholog FKHRL1 by the daf-2 insulin-like signaling pathway. Curr Biol 11(24):1950-1957.

92. Petriv OI \& Rachubinski RA (2004) Lack of peroxisomal catalase causes a progeric phenotype in Caenorhabditis elegans. J Biol Chem 279(19):19996-20001.

93. Vanfleteren JR (1993) Oxidative stress and ageing in Caenorhabditis elegans. Biochem J 292 ( Pt 2):605-608.

94. Olahova M \& Veal EA (2015) A peroxiredoxin, PRDX-2, is required for insulin secretion and insulin/IIS-dependent regulation of stress resistance and longevity. Aging Cell 14(4):558-568.

95. De Haes W, et al. (2014) Metformin promotes lifespan through mitohormesis via the peroxiredoxin PRDX-2. Proc Natl Acad Sci U S A 111(24):E2501-2509.

96. Miranda-Vizuete A, et al. (2006) Lifespan decrease in a Caenorhabditis elegans mutant lacking TRX-1, a thioredoxin expressed in ASJ sensory neurons. FEBS Lett 580(2):484-490.

97. Jee C, Vanoaica L, Lee J, Park BJ, \& Ahnn J (2005) Thioredoxin is related to life span regulation and oxidative stress response in Caenorhabditis elegans. Genes Cells 10(12):1203-1210.

98. McCallum KC, et al. (2016) TRX-1 Regulates SKN-1 Nuclear Localization Cell Non-autonomously in Caenorhabditis elegans. Genetics 203(1):387-402.

99. Anathy V, et al. (2018) Reducing protein oxidation reverses lung fibrosis. Nat Med 24(8):11281135.

100. Raza H, Robin MA, Fang JK, \& Avadhani NG (2002) Multiple isoforms of mitochondrial glutathione S-transferases and their differential induction under oxidative stress. Biochem $J$ 366(Pt 1):45-55.

101. Settivari R, VanDuyn N, LeVora J, \& Nass R (2013) The Nrf2/SKN-1-dependent glutathione Stransferase pi homologue GST-1 inhibits dopamine neuron degeneration in a Caenorhabditis elegans model of manganism. Neurotoxicology 38:51-60.

102. Wells MB, Snyder MJ, Custer LM, \& Csankovszki G (2012) Caenorhabditis elegans dosage compensation regulates histone $\mathrm{H} 4$ chromatin state on $\mathrm{X}$ chromosomes. Mol Cell Biol 32(9):1710-1719.

103. Schmeisser K, et al. (2013) Role of sirtuins in lifespan regulation is linked to methylation of nicotinamide. Nat Chem Biol 9(11):693-700.

104. Ludewig AH, et al. (2013) Pheromone sensing regulates Caenorhabditis elegans lifespan and stress resistance via the deacetylase SIR-2.1. Proc Natl Acad Sci U S A 110(14):5522-5527.

105. Hoeven R, McCallum KC, Cruz MR, \& Garsin DA (2011) Ce-Duox1/BLI-3 generated reactive oxygen species trigger protective SKN-1 activity via p38 MAPK signaling during infection in $\mathrm{C}$. elegans. PLoS Pathog 7(12):e1002453.

106. Okuyama T, et al. (2010) The ERK-MAPK pathway regulates longevity through SKN-1 and insulin-like signaling in Caenorhabditis elegans. J Biol Chem 285(39):30274-30281.

107. Tang H \& Pang S (2016) Proline Catabolism Modulates Innate Immunity in Caenorhabditis elegans. Cell Rep 17(11):2837-2844. 
108. Ewald CY, et al. (2017) NADPH oxidase-mediated redox signaling promotes oxidative stress resistance and longevity through memo-1 in C. elegans. Elife 6.

109. Saksela M \& Raivio K0 (1996) Cloning and expression in vitro of human xanthine dehydrogenase/oxidase. Biochem J 315 ( Pt 1):235-239.

110. Chen H, Howald WN, \& Juchau MR (2000) Biosynthesis of all-trans-retinoic acid from all-transretinol: catalysis of all-trans-retinol oxidation by human P-450 cytochromes. Drug Metab Dispos 28(3):315-322.

111. Marill J, Cresteil T, Lanotte M, \& Chabot GG (2000) Identification of human cytochrome P450s involved in the formation of all-trans-retinoic acid principal metabolites. Mol Pharmacol 58(6):1341-1348.

112. Pratt-Hyatt M, Zhang H, Snider NT, \& Hollenberg PF (2010) Effects of a commonly occurring genetic polymorphism of human CYP3A4 (I118V) on the metabolism of anandamide. Drug Metab Dispos 38(11):2075-2082.

113. Honda A, et al. (2011) Cholesterol 25-hydroxylation activity of CYP3A. J Lipid Res 52(8):15091516.

114. Renkema GH, et al. (2015) SDHA mutations causing a multisystem mitochondrial disease: novel mutations and genetic overlap with hereditary tumors. Eur J Hum Genet 23(2):202-209. 